\title{
FAKÉREG HASZNOSÍTÁSI LEHETŐSÉGEINEK ÁTTEKINTÉSE
}

\author{
Börcsök Zoltán, Adamik Péter és Pásztory Zoltán \\ Soproni Egyetem, Simonyi Károly Kar, Innovációs Központ
}

\begin{abstract}
Kivonat
Évente mintegy 300-400 millió köbméter kéreg keletkezik a fahasznositás során. Ennek legnagyobb része azonban hasznosítatlan marad, illetve elégetik. A kéreg szerkezete és összetétele különleges, a faanyagtól különbözö, mely tulajdonságok számos hasznositási lehetőséget rejtenek. A mezőgazdaság, energetika, orvostudomány, falemezipar, szigetelöanyag-gyártás és vegyipar sikerrel használhatja és felhasználhatja a fák kérgét. Ez a tanulmány a kéreg szerkezetéröl, tulajdonságairól és a hasznositási lehetőségekröl ad áttekintést.
\end{abstract}

Kulcsszavak: kéreg, hasznositás, anatómia, összetétel.

\section{REVIEW OF THE POSSIBILITIES OF BARK UTILIZATION}

\begin{abstract}
Approximately 300-400 million cubic meters of bark are produced each year during wood processing. Most of this, however, remains unused or burned. The structure and composition of the bark are special, and differs from the wood, which features a number of utilization possibilities. Agriculture, power engineering, medicine, woodpanel industry, insulation and chemical industry can successfully use and utilise the bark of different trees. This study provides an overview of the structure, properties, and utilization potential of the bark.
\end{abstract}

Keywords: bark, utilization, anatomy, composition.

\section{BEVEZETÉS}

Az erdőgazdálkodás egyik fő célja a fatermesztés, amivel évente nagy mennyiségü megújuló nyersanyagot állít elö. A világon évente kitermelt faanyag (hengeresfa-roundwood) mennyiségét 3.591.142.000 $\mathrm{m}^{3}$-re becsülik (FAO 2015). A világon az évente keletkező kéreg mennyisége $10 \%$ kéreghányaddal számolva így közelítöleg $359.114 .200 \mathrm{~m}^{3}$. Már a XX. század közepén is nagy problémát jelentett a fakitermelésnél és -feldolgozásnál keletkező hatalmas kéregmennyiség elhelyezése, melyet a legtöbb esetben szeméttelepekre hordtak (Weissmann 1976). Feng et al (2013) szerint pl. Kanadában évente több mint 17 millió m³ 
kéreg keletkezik, aminek több mint a fele égetésre vagy hulladéklerakóba kerül. Magyarországi erdőkben kitermelt faanyagról eltávolított kéreg mennyisége évente országosan eléri az 5-600 ezer köbmétert (Molnár 2004).

A kéreg számos funkcióval rendelkezik a növény élete során, miközben maga is változik az életkortól függően. A héjkéreg igen változatos, egy-egy fafajra jellemző formákat ölthet, vastagsága függ a fafajól, a kortól és az ökológiai tényezőktől, sőt a fa egyes részeiben is más és más lehet (Fekete 1951, Gencsi 1980, Butterfield et al 1997).

A kéreg részaránya a fatesthez képest 5-28\% is lehet (Nyikosov 1985, Sopp et al 2000, Molnár 2004, Guidi et al 2008). Guidi et al (2008) Populus deltoides L. különböző korú klónjainak kéregarányát vizsgálták, hiszen a fás biomassza kéreg aránya közvetlenül érinti a minőséget és gazdasági értéket. Kis átmérők esetén a kéreg mennyisége gyorsan csökken, egészen kb. 4 cm-ig, aztán az arány állandósul.

\section{A KÉREG ANATÓMIÁJA, FUNKCIÓJA}

Az elsődleges növényi szárat elsődleges börszövet az epidermisz borítja, sejtjei vékony falúak, egymáshoz szorosan illeszkednek, a külvilág felé pedig jelentős mennyiségü viasz borítja (Haraszty 1988, Gyurján 1996). A fás növényekre jellemző, hogy több évig élnek, és az élettartamuk alatt folyamatosan növekszenek, ami együtt jár a hajtások megvastagodásával is, amivel az elsődleges bőrszövet csak egy rövid ideig tud lépést tartani, általában felszakad (Fodor 2004). Ezzel együtt általában az elsődleges kéreg belső részeiben egy sejtsor újra osztódóvá válik (parakambium vagy más néven fellogén), és új szövetet hoz létre: kifelé parabőrt (fellom), befelé paraalapszövetet, vagy másodlagos kérget, más néven fellodermát. A fellom sejtjei a kialakulásuk után gyorsan elhalnak, miközben a sejffalba szuberin rakódik, és a víz számára teljesen, gázok számára majdnem teljesen átjárhatatlanná válnak. A felloderma sejtjei az elsődleges kéreghez hasonlók, parenchimatikusak. A több évig élő fás növények szárában a parakambium évröl-évre egyre mélyebben alakul ki és idővel behatol a háncsba, és az ott található élő sejtekböl háncsparenchimákból alakulnak ki. Innentöl kezdve a felületi szövet már nem csak a parakambium által létrehozott fellom sejjjeiből áll, hanem közé keverednek a háncsból származó elemek, mint a háncsrostok, rostasejtek, rostacsövek is (Ghosh 2006). Az így létrejövő, több év alatt megvastagodó, általában jellegzetes módon felrepedező szövetet nevezik harmadlagos kéregnek vagy héjkéregnek (ritidóma).

A legkülső rétegek gyakran jellegzetes kéregcserepek formájában leválhatnak a felületröl. A ritidóma legfontosabb feladata, hogy külső hatásoktól, mechanikai sérüléstöl védje a hajtást, megakadályozza a vízvesztést, illetve csökkentse a fagyhatást (Oskolski et al 2010). 


\section{A kéreg védelmi funkciója}

A fák kérge organizmusok tucatjainak nyújt otthont: különböző ízeltlábúak, gerincesek, zuzmók, mohák és egyéb élölény lakhelyeül szolgál. A legtöbb egyed nem „rongálja” életének környezetét, viszont vannak bizonyos élölények, melyek ottlétükkel károsítják azt: pl. a szúfélék (Popp et al 1991).

A kéreg nem csak az időjárási viszonyoktól, a vadrágástól, a rovarkárositóktól védelmezi a fát, de erdőtüzek esetén is döntő szerepet játszik. Kimutatták, hogy a kéreg relatív vastagsága jelentősen befolyásolja a fák túlélését a tüzben (Schafer et al 2015, Catry et al 2010, Lawes et al 2011, Wang et al 2011, do Vale \& Elias 2014, Dickinson \& Johnson 2001, Dickinson 2002). Megállapították, hogy a kéreg tüzállósága függ a vastagságától és, hogy a fafajok közötti eltérő fizikai tulajdonságok csak elhanyagolható mértékben játszanak befolyásoló szerepet, és a fö paraméter egy adott kéregnél a vastagság és a nedvességtartalom (Bauer et al 2010, Hengst \& Dawson 1993).

\section{A kéreg, mint a légszennyezés indikátora}

A kéreg azért kiváló bioindikátor, mert folyamatosan ki van téve az esetleges légszenynyezésnek, ráadásul struktúrájából, porozitásából adódóan nagy felületen érintkezik a levegővel, és tovább megőrzi a szennyeződést, mint pl. a levelek felszíne, ahonnan az eső könynyen lemoshatja (Härtel 1982, Böhm et al 1997, Saarela et al 2005, Mandiwana et al 2006). Így akkor is kimutatható a szennyezés, ha a levegőben éppen nem található szennyezöanyag. A fák kérgének savassága, illetve annak növekedése jó használható a légszennyezés mértékének becslésére (Grodzinska 1971, 1978, 1979, 1982, Lötschert 1983, Staxäng 1969, O'Hare 1974, Swieboda \& Kalemba 1979, Santamaría \& Martin 1997, Kuang et al 2006, Marmor \& Randlane 2007, Sawidis et al 2011, Steindor et al 2011). Számos fafajt, így tölgyeket (Quercus sp.), szileket (UImus sp.), füzeket (Salix sp.), nyárakat (Populus sp.), kőriseket (Fraxinus sp.), juharokat (Acer sp.), hársakat (Tilia sp.), fenyő fajokat (Pinus sp.), tiszafát (Taxus baccata L.), akácot (Robinia pseudoacacia L.) olajfát (Olea europea L.), cédrust (Cedrus atlantica Endl.), ciprust (Cupressus sempervirens L.), eukaliptusz fajokat (Eucalyptus sp.) és másokat is felhasználtak már fém és egyéb szennyeződések kimutatására (Barnes et al 1976, Fatoki \& Ayodele 1991, Lippo et al 1995, Saarela et al 2005, Poikolainen 1997, Schulz et al 2000a, 2000b, El-Hasan et al 2002, Mandiwana et al 2006, Gemici et al 2006, Kuang et al 2006, Suzuki 2006, Berlizov et al 2007, Han et al 2008, Steindor et al 2011). A kéreg meg is örzi a múltbeli szennyeződéseket, így a sérülések hatására keletkező kéregbenövések segítségével kis mintákból vontak le következtetéseket történelmi távlatú ólom szennyeződésekre, illetve a szennyeződés intenzitásának, forrásának változásaira (Satake et al 1996, Bellis et al 2002a, 2002b, Wang et al 2003, Åberga et al 2004, Conkova \& Kubiznakova 2008). 


\section{A KÉREG FIZIKAI ÉS KÉMIAI JELLEMZŐI}

\section{Nedvességtartalom}

A kéreg nedvességtartalma széles sávban mozoghat, és számos tényező befolyásolhatja: fafaj, tárolás fajtája (nedves vagy száraz), évszak, a kéreg eltávolításának módja, valamint érte-e csapadék az eltávolított kérget (Corder 1976). A háncs nedvességtartalma általában 7-10-szer nagyobb, mint a héjkéregé, tehát a kéreg átlagos nedvességét döntően befolyásolja a háncs és a héjkéreg mennyiségi aránya. A fakitermelést követően a kéreg átlagos nettó nedvességtartalma még igen nagy, pl. az erdeifenyőnél átlag 120\%, a lucfenyőnél $112 \%$, a bükknél $127 \%$, a nyírnél $58 \%$, de a körülményektöl függően akár $150 \%$ fölé is mehet (Corder 1976, Clark et al 1985, Ugolev 1986, Dibdiakova et al 2014). A héjkéreg a rönktéri tárolás során a legtöbb fafajnál viszonylag gyorsan veszíti víztartalmát. A fürészüzemi kérgezésig a pikkelyes kérgü luc- és erdeifenyőnek az átlagos nettó nedvességtartalma 60-70\%-ra csökken, míg a gyürüsen leváló nyíré gyakorlatilag nem változik (Ugolev 1986). A kéreg tömegre számított fütóértéke gyakorlatilag megegyezik a fatestével 17-25 $\mathrm{MJ} / \mathrm{kg}$ (Corder 1976, Németh et al 1983). A tüzeléstechnikai szempontból azonban figyelembe kell venni a tüzelőanyag térfogatát is. Németh et al (1983) vizsgálatai szerint lényegesen kedvezőtlenebbek a kéreg jellemzői: pl. az abszolút száraz akác fatest fütőértéke 13 $526 \mathrm{MJ} / \mathrm{m}^{3}$, a kéregé pedig $4983 \mathrm{MJ} / \mathrm{m}^{3}$ volt.

\section{Sürűség}

Polubojárinov vizsgálta a kéreg sürüségét, légszáraz (12\%) állapotban a következő eredményeket kapta: tölgy (kocsányos, kocsánytalan): $480 \mathrm{~kg} / \mathrm{m}^{3}$, rezgö nyár: $590 \mathrm{~kg} / \mathrm{m}^{3}$, erdei fenyő: $370 \mathrm{~kg} / \mathrm{m}^{3}$ (Polubojárinov 1976). Miles and Smith (2009) 156 észak-amerikai fafaj adatait szedte össze. A legtöbb faj esetében $400-500 \mathrm{~kg} / \mathrm{m}^{3}$ értékeket mértek, de néhány tölgyfaj esetében a sürüség elérte a $750 \mathrm{~kg} / \mathrm{m}^{3}$-t, más fajoknál viszont (pl. egyes Pinus-ok) $300 \mathrm{~kg} / \mathrm{m}^{3}$ alatti érték adódott. Természetesen sürüség és fajsúly számos tényezőtől függhet, pl. életkortól, földrajzi elhelyezkedéstöl, stb. (Patrick et al 2009).

\section{Kémiai összetevők}

A kéreg elemi összetételét tekintve a fatesttöl lényegesen csak a hamualkotókban tér el (1. táblázat).

A háncs és a héjkéreg jóval gazdagabb ásványi anyagokban, mint maga a fatest. $A z$ értékek a fajok között jelentős mértékben eltérnek, száraz tömegre vonatkoztatva 1,5 és 10\% közötti értekek fordulnak elő a különböző irodalmakban (Chang \& Mitchell 1955, Millikin 1955, Corder 1976, Szendrey, 1986, Naunes et al 1999, Barboutis és Lykidis 2014, Han és Shin 2014). A hamuban Al, Mn, Mo, Ca, P, Mg, Zn, Cu, Fe, B, N, K, Ni, Cr, Pb, Si, Na 
mutatható ki, és a Ca, N, K a domináns általában (Young 1971, Lambert 1981, Ragland \& Aerts 1991, Olander \& Steenari 1995, Piotrowska et al 2012, Miranda et al 2012, Wang \& Dibdiakova 2014). Millkin (1955) számos faj esetében a fö elemeket is meghatározta, s megállapította, hogy a nyitvatermők esetében a széntartalom $50 \%$ fölötti, míg a zárvatermő fajok esetében kissé nagyobb a szórás, és esetenként $50 \%$ alatti értéket is mért.

1. táblázat A lucfenyő fatestének és kérgének elemi összetétele (\%) (Ugolev 1986)

Table 1. The elemental composition of the spruce wood and bark (\%) (Ugolev 1986)

\begin{tabular}{|c|c|c|c|c|}
\hline & Szén & Hidrogén & Oxigén & Egyéb elemek \\
\hline Fatest & 50,0 & 6,0 & 43,5 & 0,5 \\
\hline Háncs & 51,5 & 5,7 & 38,8 & 4,0 \\
\hline Héjkéreg & 44,4 & 6,4 & 45,4 & 3,8 \\
\hline
\end{tabular}

\section{Szervesanyag összetétel}

A háncs és a héjkéreg szervesanyag-összetételére jellemző a viszonylag kevés cellulóz. Míg a fatestben $40-50 \%$ cellulóz található, addig a háncsban $18-25 \%$, a héjkéregben pedig mindössze 3-17\% (Ugolev 1986). Más kutatások összességében vizsgálták a kérget, és ilyen drasztikus különbséget nem mutattak ki (Harkin \& Rowe 1971, Usta \& Kara 1997, Melin 2008, Dibdiakova et al 2014).

Természetesen a cellulóz mellett a másik fö összetevő a lignin, mely szintén jelentös mennyiségben van jelen a kéregben (Naunes et al 1999, Fradinho et al 2002, Jové et al 2011, Miranda et al 2012, 2013, Feng et al 2013).

Jellemző a kéregre a parásodáshoz nélkülözhetetlen szuberin jelenléte is (Cordeiro et al 1998, Gandini et al 2006, Graça \& Santos 2006, Coquet et al 2008, Jové et al 2011, Miranda et al 2012, 2013). Jové et al (2011) Quercus suber kérgét vizsgálták: szuberin és lignin volt a két legnagyobb mennyiségben előforduló anyag.

A kéreg fontos összetevői a járulékos anyagok és másodlagos anyagcseretermékek, melyek viszonylag jelentős mennyiségben (akár 20\%) vannak jelen a kéregben, és gyakran egy-egy családra, nemzetségre jellemzők. Fernandes et al (2011) célja az volt, hogy azonosítsa a kivonható fenolos vegyületeket a Quercus suber L. parafájából. Harminchárom vegyületet azonosítottak, melynek legtöbbje galluszsav-származék, valamint gallotanninok, ellagitanninok, ellagsav származékok. Mások kis molekulasúlyú fenolos savak és aldehidek voltak. A járulékos anyagok közül különösen a cserzőanyagok jelenléte a jellemző. A korábbi évtizedekben csersavtermeléshez felhasználták a tölgyek, a lucfenyő, a füzek és a szelídgesztenye kérgét is, mivel csersavtartalmuk jelentősen meghaladja a fatestét. A cserzőanyagokat bőrök kezelésére használták (Portik 2006).

A frissen leválasztott háncs nedvei 55-60\%-ban erjeszthető cukrokat (glukózt, fruktózt, mannózt) tartalmaznak (Szendrey 1986). 
Abyshev et al (2007) Betula pubescens Ehrh. kérgének kivonatát vizsgálva a következő vegyület-csoportokat találták: terpenoidok $(75,2 \%)$, ezek észterei $(4,4 \%)$, éter-olajok $(0,08 \%),(6,3 \%)$, és azok epoxidjai $(1 \%)$, szteroidok ( $\beta$-szitoszterin $2,7 \%)$, tanninok $(2,1 \%)$, flavonoidok (1,56\%), hidroxikumarinok (0,85\%), és számos azonositatlan vegyület (kb. $4 \%$ ). Narasimhachari és von Rudloff (1961) Juniperus horizontalis Moench vizsgálata során thujopsent, 1-cedrént, cuparetlet, cedrolt, widdrolt, 8-szitoszterint, zsírsav-észtereket és a $\beta$ szitoszterin, a lignán savinin, és diterpene communic savat izoláltak. Vázquez et al (2008) faiparból hulladékként származó Eucalyptus globulus Labill. kéreg antioxidáns aktivitását és teljes fenol tartalmát vizsgálták. A nem-cellulóz monoszacharidok közül kimutatható pl. arabinóz, xilóz és mannóz nagyobb mennyiségben (Miranda et al 2012). Fradinho et al (2002) Pinus pinaster Aiton -t vizsgálták, megállapították, hogy a kondenzált tanninokat föként katechin típusú szerkezeti egységek alkotják. Rowe et al (1969) természetes a transzés cisz-pinosylvin dimetil-étert (3,5-dimetoxi-cisz-sztilbén) izolálták Pinus banksiana Lamb. kéregböl. Ezen kívül ferulinsav viasz-alkohol-észtereit, dehydroabietic sav és azok diterpénjeit, és phlobatannin észtereket. Feng et al szerint (2013) szerint a kéreg nagy mennyiségü extraktumot és lignint (akár a száraz tömeg 50\%-a) tartalmaz, amely vegyi anyagok, különösen az aromás vegyi anyagok megújuló forrása lehet. Thalhamer \& Himmelsbach (2014) Quillaja saponaria (L.) Molina kérgéből quillaja-szaponinokat mutattak ki. Lin et al (2013) Juglans mandshurica Maxim. kérgéböl új dibenz perilén-származékokat mutattak ki. Kemppainen et al (2014) forró vizes kezeléssel lucfenyő kérgéből kondenzált tanninokat nyertek ki, azonban a magas cukortartalma miatt a nyers extraktumot kezelni kell a használat elött. Normand et al (2014) szintén Picea abies (L.) H. Karst. kéreg forróvizes kezelésével olyan szénhidrátokat nyert ki, melyek az immunrendszer makrofágjait stimulálták.

A paratölgy kérgét többen is vizsgálták. Castola et al (2002) különböző helyekröl származó Quercus suber mintákban többek között betulint, betulinsavat, szitoszterolt és sitost4-en-3-ont azonosítottak, melyek segítségével a származási helyeket is azonsoítani tudták. Santos et al (2010) Quercus suber parafát vizsgáltak, 15 fenolos komponenst azonosítottak, pl. ellágsavat, galluszsavat és protokatechid savakat, szalicilsavat, eriodictyolt, naringenint, kinasavat és hydroxyphenyllactic savat. Pinto et al (2009) pedig hidroxizsírsav származékokat mutatott ki mind parafából, mind Betula pendula kéregből.

\section{KÉRGEZÉSI ELJÁRÁSOK}

A kéreg feldolgozásának módját meghatározza az eredete, a mennyisége, az összetétele, a nedvességtartalma, valamint nem utolsó sorban a megjelenési formája, mérete. A kéreghulladék háncstartalma, nedvességének a kitermelés időpontjától, valamint a tárolás körülményeitől függő ingadozásai hatnak az alkalmazott technika kiválasztására. Az aprítást általában olyan berendezésekkel végzik, amelyek a hengeresfa, vagy más fahulladék feldolgozására is alkalmasak (Szalay 1981). 
Többféle kérgezési technológia áll rendelkezésre: marófejes kérgezők, kalapácsos kérgezők, forgógyürüs vagy forgókéses kérgezőgépek, dobkérgezők, kérgezés vízsugárral, nagyfrekvenciás kéregtelenítés (Hargitai 2003, Baroth 2005, Ressel 2006). Egy tömör $\mathrm{m}^{3}$ kéreg felapritásához a kéregjellemzőktöl függően körülbelül 5-20 kWh villamos energia szükséges (Hargitai 2003).

A kérgezés folyamatát számos tényező befolyásolja. Elsősorban a fafaj, illetve a rönk dimenziói, a háncsrostok és szklereidák jelenléte, a kéreg szívóssága fontos, de kimutatták, hogy a faanyag nedvességtarttalma is jelentős befolyásoló tényező, mivel befolyásolja a kéreg-fatest közötti kötés erősségét (Einspahr et al 1984, Chow \& Obermajer 2004). Természetesen a tárolás körülményei sem hanyagolhatók el, valamint magas nedvessétartalom esetén a hömérséklet is befolyással van (Baroth 2005).

\section{A KÉREG FELHASZNÁLÁSÁNAK LEHETŐSÉGEI}

Az ősi időkben ugyanolyan természetes volt a kéreg felhasználása, mint a fa többi részének. Számos faj kérgét felhasználták, pl. az áztatott szilkéreg (Ulmus sp.) jó a borjaknak, ugyanakkor mivel rostos, széles körben használták kötélfonáshoz, de előfordult, hogy ruhát varrtak belőle. Norvégiában az 1812-es éhínség alatt tett nagy szolgálatot, kérgét megették (Coleman 1998, Richens 1983). A különböző Pinus fajok kérgét télvégi ínséges időkben táplálékként hasznosították pl. Skandináviában (Östlund et al 2009).

A különböző fafajok kérgei között jelentős különbségek vannak. Ezen különbségek jelentős mértékben határozzák meg a felhasználási lehetőségeket.

\section{Orvostudomány}

Az első gyógyszereket a növények szolgáltatták. Hatóanyagaik közé tartoznak az alkaloidák, illóolajok, szénhidrátok, vitaminok, antibiotikumok. Több fajtájuk az illatszerészet gyakran alkalmazott illatot adó vagy illatot rögzítő anyaga. A gyógyszerészetben tapaszok, kenőcsök, bedörzsölő szerek, hajvizek és többféle más készítmények alkotórészeként szerepelnek. A csersavtartalmú növények teáit belsőleg gyomor- és bélvérzés, gyomor- és bélhurut ellen, hasmenés megszüntetésére használják, külsőleg fogíny ecsetelésére, toroköblögetésre, fagyott vagy gyulladásos testrészek borogatására, izzadság meggátlására, aranyerés képződmények fürdetésére (Rábóti et al 1997).

A népi gyógyászat az akác, a füz, a kőris, a szil és a tölgy kérgének főzeteit számos betegség ellen használta (Rápóti et al 1974). Számos faj kérgét használták, használják gyógyszerként, Európában pl. a Chondrodendron tomentosum Ruiz \& Pavón kérgének vagy levelének besürített vizes kivonata a kuráre, amivel mütéteknél a simaizmok gátlását oldották meg. A Cinchona pubescens Vahl kérge adja a kinint, ami sokáig a malária fő gyógyszere volt (Poyraz \& Mat 2014). A Frangula alnus Mill. kéreg hashajtó, antivirális és antifungális 
hatású. A Quercus robur L. és Q. petraea (Matt.) Liebl. főzetét bőr- és nyálkahártya gyulladások kezelésére alkalmazhatjuk. A Cinnamomum cassia kérge nem csak füszer, hanem antibakteriális és antifungális hatású, ráadásul remek étvágyjavító (Annegowda et al 2012). A Salix alba L. és S. fragilis L. kéreg kiváló fájdalom- és lázcsillapító, az Aesculus hippocastanum $\mathrm{L}$. kérge pedig hasmenés, aranyér, valamint különféle börbetegségek esetén alkalmazható sikerrel (Tóth 2005). Az afrikai Warburgia salutaris (Bertol.f.) Chiov. kérgét és levelét megfázásos tünetek, köhögés kezelésére használják (Kotina et al 2014). A Robinia pseudoacacia L. kérgének fözetét gyomorsavtúltengés, székrekedés, gyomor- és bélfekély ellen használják (Rabóti et al 1997). A Magnolia fajok kérgét hagyományosan alkalmazzák kínai és japán gyógyszerekben (Liu et al 2007). A teafa vizes kéreg kivonatának hatására csökken a vércukorszintet és javul az anyagcsere (Vasconcelos et al 2011). A Brazíliában őshonos Byrsonima intermedia $A$. Juss. fajt régóta használják vérzés, hasmenés ellen, illetve gyulladáscsökkentőként (Orlandi et al 2011). A Cariniana rubra kérgét gyulladásos állapotok kezelésére használják (Santos et al 2011). A Szub-szaharai Afrikában a Garcinia buchananii Welw. ex Oliv. szár kérgét használják hasmenés elleni orvosságként (Boakye et al 2012). Az Acacia mangium Willd. kérgében, nagy koncentrációban fenolos vegyületek vannak jelen, melyek különböző módon jótékony hatást gyakorolnak az emberi szervezetre (Zhang et al 2010). A kameruni és a madagaszkári erdőkben élő afrikai meggy kéregből készített kivonat kiváló gyógyszerként szolgál prosztatabántalmak elháríására (Szodfridt 2003). Kiran és Chandrakant (2009) szerint a Careya arborea Roxb. kéreg terpenoid, flavonoid, alkaloid, szaponin és tannin tartalma májvédő és in vivo antioxidáns tulajdonságokkal bír. Terangpi et al (2013) szerint az Acacia pennata (L.) Maslin kérgét a hagyományosan rizs erjesztése során használják fel. Az afrikai Sclerocarya birrea (A. Rich.) Hochst. egy afrikai növény kéregét hagyományosan vérhas, hasmenés, és különböző egyéb fertőző betegségek kezelésére használják Sarkar et al (2014). Ponomarenko et al (2014) megállapították, hogy az Alnus incana (L.) Moench kérgéböl izolált kétféle nem ciklikus diarilheptanoid hatékony antioxidáns. Navid et al (2014) nyírfakéreg (Betula pendula) pentaciklusos triterpénjeinek (betulin, lupeol és betulinsav) antivirális tulajdonságait vizsgálták, és megállapították, hogy magas szintü vírusellenes aktivitással rendelkeznek bizonyos herpeszvírus törzsek ellen. Comandini et al (2014) Castanea sativa Mill. kéregböl hét vegyület elválasztását és mennyiségi meghatározását oldotta meg (vescalin, castalin, galluszsav, vescalagin, 1-0galloil castalagin, castalagin és ellagsav). Módszerük információkat nyújthat az étrend-kiegészitökben kereskedelmi forgalomba kerülö gesztenye kéregminták összetételére és minőségére. Jyske et al (2014) a bioaktív sztilbén glükozidok (astringin, isorhapontin, és piceid) jelenlétét vizsgálta Picea abies-ben. Az Acanthopanax sessiliflorus (Rupr. \& Maxim.) Seem. fás cserje kérgét hagyományosan rákellenes aktivitásúnak tartják. Venkatesan et al (2015) emberi emlörák sejteken bizonyította ebböl a fajból készült kéregkivonat hatásosságát. A Quercus ilex L. kéreg antibakteriális hatása a kivonás körülményeitöl, az oldószertöl függött, de többféle módszer is hatásosnak bizonyult (Berahou et al 2007). Diouf et al (2009) Picea mariana (Mill.) Britton et al kérgéből antioxidáns és gyulladás gátló anyagokat mutattak ki. 
Kim et al (2015) megállapították, hogy fahéj kérgének illóolajai hatékonyan gátolják a Pseudomonas aeruginosa biofilm képzését, valamint más alkotók a baktérium rajzását, illetve hemolitikus aktivitását csökkentik. Grace et al (2003) 174 afrikai fásszárú fajt foglaltak adatbázisba, melyeket a hagyományos gyógyászatban használnak.

\section{Energetikai hasznosítás}

A nyersanyaghiány miatt egyre inkább szükségesé vált az alternatív tüzelőanyagok felkutatása, így került sor a kéreg tüzelésére. Az energetikai hasznosítást leginkább az befolyásolja, hogy a kéreg hamutartalma a fatesténél jóval magasabb, így az energetikai hasznositás során jelentős mennyiségü hamuval kell számolni. Egy tanulmány szerint reális lehetőségek rejlenek az európai erdőkben, a fa energetikai célú hasznosítása az elkövetkező években növekedni fog (Verkerk et al 2011). Harkin et al (1971) megállapították, hogy tíz tonna teljesen kiszárított kéreg átlagos bruttó fütőértéke egyenértékű 7 tonna szén fütőértékével.

A kéreg kilogramra vetített fütőértéke a fanyaghoz hasonló: 16,2-23 MJ/kg (Corder 1976, Pecznik \& Körmendi 1997, Dibdikova et al 2014). A tömegesen keletkező kéreghulladéknak azonban általában magas nedvességtartalma, ami jelentösen csökkenti az energetikai hasznositás hatékonyságát, mivel az energia jelentős részét a kéreg nedvességtartalmának elpárologtatása emészti fel. $60 \%$ nettó nedvességtartalom felett a kéreg nem tüzelhető el hatékonyan (Molnár 2004).

A kéreg brikettként való hasznositásánál általában összekeverik szalmával, fürészporral. Viasz hozzáadása javítja a biobrikett szilárdságát, de az adalékanyagnak lehet nedvességtartalom csökkentő szerepe is. Legföbb jellemzője a nagy sűrüség, illetve tömörség (1-1,3 $\left.\mathrm{g} / \mathrm{cm}^{3}\right)$ (Baros 2003). Norvégiában erdei fenyő kérgét vizsgálták, mint potenciális nyersanyag. A kísérlet 5, 10, 30 és 100\%-os kéregtartalommal folyt. A tartósság az összes osztályban azonos minőségü volt. Sürüsége magasabb volt, mint a tiszta fa pelleté. Minél több kéreg volt a keverékben, a hamutartalom annál inkább nőtt. A kísérlet során elért eredmények alapján a legjobb minőségi osztályt a 10\%-os keverési arány érte el, 0,7\%-os hamutartalommal (Filbakk et al 2011).

Melin (2008) megállapította, hogy a kéreg kiválóan alkalmazható pellett gyártására. A kéregben található, a magas nyomáson könnyebben megolvadó anyagoknak köszönhetően a részecskék között erős a kötés, ezért kedvezőek a kéregböl készült pellet fizikai, mechanikai tulajdonságai. Hátrányok között ő is a magas hamutartalmat említi, valamint olyan anyagok jelenlétét (kloridok, szulfátok, stb.), melyek speciális intézkedéseket követelnek meg. Hasonló eredményekre jutott Lehtikangas (2001) is, aki az alkalmasság mellett megállapította, hogy a kéregböl készült pelletnek kiváló a tartóssága, és a nedvességet is jól bírja. Obernberger és Thek (2004) a megnövelt sürüségü biomassza-üzemanyagok szabványoknak való megfelelőségét vizsgálta. Így a sürüséget, a víz- és hamutartalmat, a bruttó és a nettó fütőértéket, a kopást, a a $\mathrm{C}, \mathrm{H}, \mathrm{N}, \mathrm{S}, \mathrm{Cl}, \mathrm{K}$, valamint $\mathrm{Cd}, \mathrm{Pb}, \mathrm{Zn}, \mathrm{Cr}, \mathrm{Cu}$, As és $\mathrm{Hg}$ tartalmat. Megállapították, hogy a vizsgált pelletek megfelelnek az osztrák, német, svájci és 
svéd szabványoknak. Kamikawa et al (2009) megállapították, hogy bár a kéregböl kinyerhetö összes hőmennyiség nem tér el a fatestböl készülttöl, mégis van különbség: a kéregpellet kevesebb hőt ad le a tüzelés során és többet utóizzásssal.

Gil (1997) a parafa feldolgozás során keletkező hulladék és por energiatermelésre való hasznositását javasolja, mivel magas a fütőértéke.

\section{Mezőgazdaság}

A kéreg mezőgazdasági hasznositásának legegyszerübb útja egyértelműen a talajtakarás (mulcsozás). A mulcsozás előnyei közé tartozik, hogy csökkenti a párolgást a talaj felszínén, elősegíti a talajban lévő mikroorganizmusok szaporodását, lassabban bomlik, mint a fa, és az alacsonyabb „nitrogén- fogyasztása” miatt kevesebb műtrágya szükséges, mint a faanyag bomlásakor, a nehéz talajba kevert kéreg levegőztetőként hat, megelőzi a talajtömörödést, növeli a víz felszívódását és a termőtalaj errózióját is csökkenti (Nagy et al 1998, Whiting et al 2011, Harkin et al 1971, Blossfeld 1977). Csemetekertben kéreglisztböl 2-3 cmes takaróréteget képezve, az őrlemény kémhatását mészadalékkal közel semlegesre beállítva, csaknem az erdei viszonyoknak megfelelő feltételek teremthetők - álítja Bittner et al (1975).

A kéreg természetes viszonyok között lassan bomlik, melynek fö oka, hogy nitrogéntartalma alacsony. Komposztálással fel lehet gyorsítani a bomlási folyamatokat: szabadban 4 hónapot vesz igénybe a folyamat, ha a kérget $10 \mathrm{~mm}$-nél kisebb darabokra aprítják.

A fakérgeket több éves érlelés után lehet ajánlani közvetlen termesztöközegként történő felhasználásra, mely alatt javul a humuszállapota, adszorpciós- és pufferképessége, valamint nedvesithetősége (Sári 2008). A komposztálást befolyásolja, hogy minden kéreg tartalmaz különböző mértékben védőanyagokat (pl.: gyanták, zsírok, cserzőanyagok, fenolok) (Gerencsér 2010). Asztalos et al $(1975,1977)$ tanulmánya szerint a fakéreg megfelelő elökészítéssel azonos értékűnek tekinthető a tőzeggel.

A kéreg almozási célokra is felhasználható. Elönyös tulajdonsága, hogy képes a levegő és nedvesség ammóniatartalmának megkötésére. A 4-5 mm-nél kisebb kéregörleményböl készült alom semmiféle károsító hatással nem volt a kísérleti baromfiállomány táplálkozására és súlygyarapodására. A tülevelü- és lombos fafajok kérge egyaránt felhasználhatónak bizonyult (Labosky et al 1977).

A kéreg kevéssé alkalmas közvetlen takarmányozásra. A juhokkal a silózott, aprított rezgőnyár- kéregnek feletetése nem hozott kedvező eredményeket (Dubkin et al 1978).

\section{Lapgyártás}

Számos erőfeszítést tettek már a kéregből, mint alternatív alapanyagból forgácslap és farostlemez gyártása irányában. Az egyik alapvető nehézséget a kérgen található szennyeződések okozzák (szilícium- dioxid tartalmú homok, föld). A forgácslap gyártásban ez a tény korlátozó hatású (Deppe et al 1977). Másik nehézség, hogy a kéregrészecskék arányának 
növekedése szilárdságcsökkenéssel jár együtt, hiszen a kéreg mechanikai tulajdonságai a faanyagétól elmaradnak. Dost (1971) háromrétegü tengerparti mamutfenyő faforgácslemezeket vizsgált, amelyek $0,10,20$, és 30 százalék kérget tartalmaztak és három különböző gyanta-mennyiség felhasználásával vizsgált. A kéregtartalom növekedése az összes gyantaszinten a mechanikai tulajdonságok romlását, és a dimenzionális stabilitás csökkenését okozta. Chen et al (1972) olyan forgácslapot készítettek, melyben teljes Picea abies L. egyedeket használtak fel, valamint ezt az anyagot kombinálták hagyományos kérgezett lucból készült forgáccsal. A teljes fa anyagából készült forgácslapok nem feleltek meg a szabvány hajilitó elöírásoknak, de az 1:1 arányban kérgezett luccal kevert anyagból készültek igen. Heebink (1974) Pinus contorta Douglas ex Loudon erdei apadékokat használt fel, melynek átlagos kéregtartalma $7 \%$ volt. Megállapította, hogy különböző szerkezetű forgácslemezek minden nehézség nélkül gyárthatók lennének ezekből az anyagokból. Lehmann és Geimer (1974) különböző erdei hulladékok, apadékok segítségével készített forgácslapot, és megállapította, hogy erős és stabil lapok készíthetők, amennyiben a kéregtartalom $12 \%$ alatt marad. Muszynski és McNatt (1984) Picea abies L. és Pinus sylvestris L. kérgének felhasználhatóságát vizsgálták forgácslap gyártásban. A vizsgálat során olyan forgácslap táblák készültek, melyek kéreg tartalma 0 és $100 \%$ között változott, 10\%-os lépésekben. Fizikai és mechanikai vizsgálati eredmények azt mutatták, hogy az akár 30 százalék kéreg tartalmat elérő lapok alkalmasak lehetnek bútorgyártásra. Chow et al (2008) Parthenium argentatum A.Gray faj faanyagát és kérgét vizsgálták megállapítva, hogy a faalapú farost közvetlen helyettesitésére lehet használni. Gertjejansen és Haygreen (1973) rezgő nyár kérgének hatását vizsgálták forgácslapok fizikai tulajdonságaira. Arra a következtetésre jutottak, hogy akár az egész fatörzset lehetne használni forgácslap gyártásra, feltéve hogy a törzs alsó szakaszának kérge nem kerül a lapba, mert az a lineáris stabilitást drasztikusan csökkenti. Anderson és munkatársai. (1974a, 1974b, 1974c), egy sor tanulmányt folytattak kéreg kivonattal ragasztott forgácslapokon és kéreg középső rétegü forgácslapokkal. A csak kéregből készült lapok nem voltak megfelelőek az alacsony MOR értékek és a nagy lineáris tágulási értékek miatt, de a kéreg középső rétegü forgácslapok kielégitő tulajdonságokkal rendelkeztek. Starecki (1979) egy- és háromrétegű lapokat gyártott, melyben a cellulóz- és papíripar hulladék kéreganyagát hasznosította. A kéregmennyiséget 0 és 100\% között változtatta. A hajilitószilárdság a kéregarány függvényében csökkent. Azok a kísérleti termékek, amelyeknek a középrésze 65\%-ban kéregböl állt, még megfeleltek az akkori szabványkövetelményeknek. A tisztán kéregből készült lapokhoz képest a forgács és kéreg kombinációjából álló lapok közel háromszor nagyobb hajilíószilárdságot mutattak. Egy kutatásban fekete luc (Picea mariana) kérgével kísérleteztek faforgácslemez gyártása céljából. A legjobb mechanikai tulajdonságokat egy $50 \%$-os fa- és 14\% gyantatartalomnál érték el (Blanchet et al 2000). A kéreg forgácslap- középrészben ajánlott mennyiségeiröl különböző vélemények alakultak ki. Kehr (1979) a szakirodalom elemzésével és saját megfigyelései alapján arra az álláspontra helyezkedik, hogy a középrészben 10\%-ot meghaladó kéregtartalmú faanyagot csak többlet ráfordítással járó sürüségnöveléssel lehet felhasználni. Egy tanulmány bebizonyította, hogy akár $70 \%$-al is olcsóbb lehetne a faforgácslemezek gyártása kéreg hozzáadásával, úgy, 
hogy a mechanikai tulajdonságok nem gyengülnek. A vizsgálatokat fehér nyír kéreggel végezték (Pedieu et al 2009). Nemli et al (2005) kísérleteikben akác és mimóza kérget használtak és vizsgálták a formaldehid kibocsátást, hajlítási szilrádságot, rugalmassági modulust, a belső kötés erősségét. A kéreg használatával jelentősen csökkent a formaldehid-kibocsátás és javult belső kötés erőssége. Egy másik értekezésben a PF-A és a PF-B gyanta kötési szilárdsági vizsgálatát folytatták (furnérlemez ragasztóanyag), ahol akacia kéreg porral dolgoztak különböző koncentrációban. A PF-A kötési szilárdsága növekedett, míg a PF$B$ gyanta szilárdsága nem változott (Miyazaki et al 2011). Az Acacia mangium egy gyorsan növő faj, melyet sok országban ültetnek. A fa körülbelül 10\%-os kéregtartalommal rendelkezik, melynek kb. 20\%-a extrakt anyag (tanninok) (Hoong et al 2009). A kéreg kivonatai fenol vegyületekben gazdagok és potenciálisan helyettesíthetik a fenol-formaldehid (PF) ragasztókat a rétegelt lemez iparban. A kísérletek szerint azonban a megfelelő hatás eléréséhez mügyantát is kell keverni az extraktumok mellé. (Hoong et al 2011). Gupta (2009) Pinus contorta szúkárosított kérgéből, műgyanta hozzáadása nélkül állított elő sikeresen lapokat, bár azok fizikai-mechanikai tulajdonságai nem érték el az előírásokban található minimális értékeket.

Pedieu et al (2008a, 2008b) tanulmányaiban Betula papyrifera Marshall külső kérgének hidrofób tulajdonságait vizsgálták, remélve, hogy Betula papyrifera külső kéreg részecskék javíthatják méretstabilitását a gyártott vegyes forgácslapnak. A vizsgálat eredményei egyértelmüen bizonyítják, hogy legfeljebb $45 \%$-nyi kérget felhasználva lehetne lapokat gyártani, amik a kívánt mechanikai és fizikai tulajdonságnak megfelelnek.

Winkler (1978) 4-5 mm vastagságú lapokat készítet lucfenyő kéregböl, sürüsége 900 $\mathrm{kg} / \mathrm{m}^{3}$, hajlítószilárdsága pedig $2000 \mathrm{~N} / \mathrm{cm}^{2}$ feletti eredményt mutattak.

MDF lapokat is gyártottak 4 féle fafaj (nemes nyár, jack fenyő, vörös fenyő, fehér luc) kérgének felhasználásával. A finomított kéreg rostoknak nagyobb volt a térfogatsürüsége, mint a kontroll faanyagé (Cheng et al 2006).

Különböző szigetelő lemezekként való alkalmazása gyerekcipőben jár. Ezek a lapok általában faforgáccsal/faaprítékkal vegyítve készültek, melyekben általában $25 \%$ a kéregtartalom (Harkin et al 1971). Kain et al (2013a) lucfenyő kéreg darabokat használtak befújt szigetelő anyagként egy gerendafal szigetelésének, melyen téli külső hőmérsékletet szimuláltak. Modellezték a hőmérsékleti profilt. A kéreg lassabban vezette a hőt, mint más befújással általában alkalmazott anyagok, így akár szigetelésre is alkalmazni lehet. Kain et al (2013b) hőszigetelő táblákat készítettek Pinus sylvestris, Picea abies és Abies alba Mill. kéreg felhasználásával. Megállapították, hogy hő és hangszigetelő tulajdonsága nagyon jó, és a mechanikai tulajdonságok is megfelelőek, emellett alacsony a formaldehid kibocsátása. Kain et al (2014) vizsgálatai szerint a Larix decidua Mill. kéreg alkalmas hőszigetelő táblák készítésére, melyek viszonylag alacsony hővezetési tényezővel $(0,065-0,09 \mathrm{~W} / \mathrm{mK})$ rendelkeznek. Ráadásul a táblák mügyanta és formaldehid mentesen, tannin-gyantával ragaszthatók, 
így sokkal természetbarátabbak. Egy japán értekezésben említik, hogy a Cryptomeria japonica (Thunb. ex L.f.) D.Don -t az országban széles körben használják az építőiparban, viszont kérgétől (mely rostban gazdag és tartós) megszabadulnak. Kísérleteket során a durva és a finom aprítás nem sokban különbözött egymástól, a hővezetési tényező 0,073 , illetve $0,076 \mathrm{~W} / \mathrm{mK}$ volt (Sato et al 2004).

Egy tanulmány tárgya kéreg és höre lágyuló müanyagok kölcsönhatásának vizsgálatáról szól (hajilitó, szakító szilárdság összehasonlítása). Fekete fenyő és rezgő nyár kéreg szálakat használtak kompozitok előállításához. A fekete fenyő kompozitból nagyobb szilárdságú anyagot hoztak létre, de sokkal ridegebb a viselkedése, mint a nyár kompozitnak. A legtöbb mechanikai tulajdonság alacsonyabb volt, mint a kontroll fa- műanyag kompozitok, szakító szilárdság és a nyúlási eredmények viszont jobbak lettek a kontroll anyagnál (Yemele et al 2010). Próbálkoztak már a duglász fenyő kérgének felhasználásával fröccsöntött termékek gyártásával is (Harkin et al 1971).

Castro et al (2010) parafa-alapú szendvicsszerkezetű agglomerátumokat vizsgált, melyeket repülőgépekben kívántak felhasználni. A kísérleti vizsgálatok során kiderült, hogy a szendvicsszerkezet teljesítményét alapvetően befolyásolja a parafa granulátum mérete, sürűsége és a ragasztási eljárás, és ezeket a paramétereket be lehet állítani a végső felhasználásra tervezett a szendvics-alkatrésznek megfelelően. Hernández-Olivares et al (1999) új kompozitot fejlesztettek, mely parafa-gipsz összetételü. Az eredmények azt mutatják, hogy a parafa és gipsz kompatibilis egymással, és különböző keverési arányokkal eltérő sürüségü, és eltérő funkciójú kompozitok hozhatók létre, melyek megfelelő hő és hangszigetelő tulajdonságokkal rendelkeznek.

\section{Parafa hasznosítása}

A kéreghasznositás sajátos módja a parafatermelés (pl. parafa dugók, szigetelölapok stb.), ez a paratölgy (Quercus suber L.) héjkérgéböl valósítható meg. A para sürüsége 110$200-250 \mathrm{~kg} / \mathrm{m}^{3}$, rugalmas, folyadékok számára áthatolhatatlan, gomba-, rovar- és vegyszerálló (Vajda 2006). A parasejtek tégla alakúak, a felületre merölegesen sorakoznak, tömötten záródnak, falukban paraanyag rakódik le, ennek következtében hamarosan elhalnak, nem marad bennük más, csak levegő és némi citoplazma-maradvány (Rapaics 1940). Kémiai összetétele: $58 \%$ szuberin, $22 \%$ cellulóz, $12 \%$ lignin, $8 \%$ járulékos anyagok (pl. csersav és hamualkotók). Az anyag természeténél fogva kiváló tulajdonságokkal rendelkezik: páraáteresztő, vízálló és víztaszító, fagyálló, nehezen éghető, nem zsugorodik, jó hőszigetelő (kicsi a hővezetési tényezője 0,037-0,040 W/mK), valamint jó hangelnyelő képességü, terhelhető, antisztatikus, az élősködők, gombák nem telepszenek meg benne. A para kiváló tulajdonságai azt is jól érzékeltetik, miért nyújt védelmet a fatestnek az elparásodott héjkéreg (Molnár 2004). 
Şen et al (2010) a vastag kérgü, Kelet-Európában és Kis-Ázsiában honos Quercus cerris L. paraszöveteit vizsgálták. Megállapították, hogy a Q. cerris var. cerris vastag kérge szintén alkalmas lehet dugók készítésére, de ennek előfeltétele az, hogy a külső kérget a háncstól el tudják választani. Ugyancsak megállpították (Şen et al 2011), hogy a Q. cerris var. cerris parája tipikus paraszöveti tulajdonságokat mutat, de a sejtek mérete kisebb, a sejtfal aránya nagyobb és több zárványt tartalmaz, mint a $Q$. suber. Ezek alapján elsősorban granulátum és különböző agglomerátumok (pl. szigetelések) készítésére alkalmas.

\section{Egyéb felhasználások}

A kéreg kémiai feltárása, belöle különböző vegyületek előállítása egyre inkább előtérbe kerül. Oramahi és Diba (2013) pirolízis segítségével durián kéregböl állított elő külöböző vegyületeket, így ecetsavat, metilalkoholt, 2-propanont, fenolszármazékokat. Şensöz (2003) Pinus brutia Ten. kérgéböl pirolizis segítségével bioolajat állított elő, melynek fütőértéke $31,03 \mathrm{MJ} / \mathrm{kg}$ volt. Dedriea et al (2015) Quercus robur és Q. petraea kéreg polifenol tartalmát vizsgálta, a kitermelés ideje és a tárolás függvényében. Az Acacia mearnsii De Wild. kéreg kivonat jelentős megújuló ipari forrása a természetes polimereknek, melyek bőrcserzésre és ragasztó gyártására használhatók (Venter et al 2012). Faipari szempontból érdeklődésre tarthat számot a kéregkivonatok ragasztógyártásban való alkalmazása. A fenolos anyagok $\mathrm{OH}$-csoportjai a formaldehiddel reakcióba lépnek, az így kapott kötőanyag sikerrel felhasználható a vízálló faforgácslapok és rétegelt lemezek előállításához (Anderson et al 1975, Anderson et al 1974, Saayman et al 1976).

Ha a falazótégla alapanyagához finomra örölt kéreghulladékot adagolnak, ami az égetés során kiég, akkor a pórustérfogat és ezzel a tégla hőszigetelő képessége is jelentősen fokozható. Egyidejüleg a kiégetett anyagmennyiség következtében a téglák sürüsége is csökken (Schweizer 1975, Schweiser et al 1977, Liverside et al 1977).

Norvégiában a kérget a vasutak épitésekor fagy szigetelésére használják. A vasúti pályatestek alépítményeiben, a teherhordó rétegek alatt, luc- és jegenyefenyő aprított, tömörítés nélküli kérgét használták fel a fagy elleni védekezésben (Schneider et al 1970).

\section{Víz- és gáztisztítás}

A kéreg vagy annak módosított változata víz tisztítására is használható. Számos kutató szerint az erdei-, a luc-, valamint a vörösfenyő, továbbá az éger, a hárs, a szil kérge megköti a mérgező ólom-, kadmium-, higany- és cinkionokat (Randall et al 1976). Kémiai aktivációs technikával aktív szén állitható elő az eukaliptusz kéregből, foszforsav segítségével (Patnukao et al 2008). Az aktív szenet kitűnő adszorpciós tulajdonságai révén, az ivóvíz tisztítására, a szennyvizek kezelésére, a levegő szennyeződéseinek eltávolitására, az oldószerek visszanyerésére, a cukor fehérítésére használják. Palma et al (2003) kémiailag módosított Pinus radiata kérget, valamint tanninokat használtak fémionok eltávolítására vizes oldatok- 
ból és rézbánya savas maradék vízéböl. Mivel a pH erősen befolyásolta a fémkötő képességet, a módositott tanninok kevesebb fémiont tudtak megkötni, mint a módosított kéreg. Salem és Awwad (2014) módosított naspolya (Eriobotrya japonica (Thunb.) Lindl.) kéreggel sikeresen távolított el nikkel ionokat vízből. Kafle et al (2015) fakéreg-alapú bioszürők hatékonyságát tesztelték sertés telepek szennyvizének szag, $\mathrm{NH}_{3}$ és $\mathrm{H}_{2} \mathrm{~S}$ mentesitésében. Megállapították, hogy ezen bioszürők hatékonyan alkalmazhatók a sertésgazdaságokban, és meghatározták azokat a nyomás és időparamétereket, melyek a szürők tervezéséhez szükségesek. Cutillas-Barreiro et al (2014) Pinus pinaster Aiton kérget használtak fel kísérletükhöz, kimutatták, hogy a kéreg a $\mathrm{Pb}^{2+}, \mathrm{Cu}^{2+}, \mathrm{Cd}^{2+}, \mathrm{Zn}^{2+}, \mathrm{Ni}^{2+}$ ionok jelentős részét megköti, így hatékonyan lehet használni szennyezett környezetben vizek nehézfémion mentesitésére. Vajda (2002) tanulmányában olajjellegü vegyületek távolítottak el a szennyvízből fakéreg segítségével. Az eredmények azt jelzik, hogy az olajsavtartalmú emulziók kéreggel való kezelése jó hatásfokkal távolítja el a szennyvizekböl a lipideket.

Nemcsak vizek, hanem gázok tisztitását is vizsgálták. Füstgáz kezelésére Pinus sylvestris kéregből készült biofiltereket alkalmaztak üzemi hőmérsékleten és nyomáson (Andres et al 2006).

Valentín et al (2010) Pinus sylvetris kérgén kívántak gombákat (Phanerochaete velutina és Stropharia rugosoannulata) felszaporítani, hogy azok hidrolitikus és ligninolitikus enzimeket, peroxidázokat termeljenek, s így bevethetők legyenek szennyezett környezet megtisztítására. Az eredmények azt jelzik, hogy a Pinus sylvetris kéreg elősegíti az enzimek termelését és biztosítja a tápanyagokat a gombák számára, így a fenyőkéreg alkalmas lehet a gombás bioremediációra.

\section{Műanyag és töltőanyag gyártás}

Cordeiro et al (1997) suberin alapú poliuretán előállítását és karakterisztikáját vizsgálta, míg García et al (2015) polifenol-alapú poliuretán (PU) fóliákat állítottak elő Pinus piraster kérgéből származó kondenzált tanninok és hidroxil-tannin-származékok, valamint diizocianátok segítségével.

Muñoz et al (2013) Eucalyptus nitens (H.Deane \& Maiden) Maiden kérgének rostjait vizsgálták, és megállapították, hogy a tulajdonságai alkalmassá teszik, hogy höre lágyuló müanyagok, mint például a nagy sürűségü polietilén (HDPE), erősítő anyagának használják.

Heinämäki et al (2015) megállapították, hogy Betula spp. kéregből kivont szuberinből származó zsírsavak, kis koncentrációban is jelentősen javítják hidroxipropil-metilcellulóz filmek párazáró tulajdonságait.

\section{Hasznosítás ruhaként és edényként}

Li et al (2014) 7900 éves kéregből készült ruha maradványait találták meg Dél-Kínában. Kéregböl még ma is készülnek ruhák, Robertson (2014) az Afrikában honos Ficus natalensis Hochst. kérgéből készülő ruhák hagyományos készítését írta le. Ösidők óta hasznositották 
még a kérget kötöző vagy csomagoló anyagként is (Östlund et al 2009). Egyes tájakon ma is fellelhető kéreg (háncs) edény készitéséhez elsősorban a nyír kérgét használják, de alkalmas a hársé, egyes nyár- és szilfajoké is. A különböző kosarakat, tálakat, tárolóedényeket (kászú, szapú, véka) a spirál alakban lefejtett, vízben áztatott kéregböl fonják. A könnyü kéregedények több évtizedig használhatók (pl. gomba-, gyümölcsszedés stb.). A nyír kérgéböl még bocskort is fontak (Szatyor 1986).

\section{KÖSZÖNETNYILVÁNÍTÁS}

A tanulmány a „Fenntartható Nyersanyag-gazdálkodási Tematikus Hálózat - RING 2017" címü, EFOP-3.6.2-16-2017-00010 jelü projekt részeként a Szechenyi2020 program keretében az Európai Unió támogatásával, az Európai Szociális Alap társfinanszírozásával valósul meg.

\section{FELHASZNÁLT IRODALOM}

Åberga G., Abrahamsen G., Steinnes E. \& Hjelmseth H. 2004: Utilization of barkpockets as time capsules of atmospheric-lead pollution in Norway. Atmospheric Environment 38: 6231-6237. DOI: 10.1016/j.atmosenv.2004.06.041

Abyshev A.Z., Agaev É.M. \& Guseinov A.B. 2007: Studies of the chemical composition of Birch bark extracts (Cortex betula) from the Betulaceae family. Pharmaceutical Chemistry Journal 41(8): 419-423. DOI: 10.1007/s11094-007-0091-5

Anderson A.B., Wong A. \& King T.W. 1975: Douglas-Fir and Western Hemlock Bark Extracts as Bonding Agents for Particleboard. Forest Products Journal 25(3): 45-48.

Anderson A.B., Wong A. \& Wu K.-T. 1974a: Utilization of white fir bark in particleboard. Forest Products Journal 24(1): 51-54.

Anderson A.B., Wong A. \& Wu K.-T. 1974b: Utilization of white fir bark and its extract in particleboard. Forest Products Journal 24(7): 40-45.

Anderson A.B., Wong A. \& Wu K.-T. 1974c: Utilization of Ponderosa pine bark and its extract in particleboard. Forest Products Journal 24(8): 48-53.

Andres Y., Dumont E., Le Cloirec P. \& Ramirez-Lopez E. 2006: Wood bark as packing material in a biofilter used for air treatment. Environment Technology 27(12): 1297-1301. DOI: 10.1080/09593332708618747

Annegowda H.V., Gooi T.S., Awang S.H.H., Alias N.A., Mordi M.N., Ramanathan S. et al. 2012: Evaluation of Analgesic and Antioxidant Potency of Various Extracts of Cinnamomum iners Bark. International Journal of Pharmacology 8(3): 198-203. DOI: 10.3923/ijp.2012.198.203

Asztalos J. \& Szabó P. 1975: A fakéreg hasznositása Lengyelországban. Faipar 25(12): 363-366.

Asztalos J. 1977: A fakéreghasznosítás irányzatai a szocialista országokban. Faipar 27(8): 239-244.

Barnes D., Hamadan M.A. \& Ottaway J.M. 1976: The lead, copper and zinc content of tree rings and bark. The Science of Total Environment 5: 63-67. DOI: 10.1016/0048-9697(76)90024-3

Baroth R. 2005: Literature review of the latest development of wood debarking. Report A No 27, August 2005. University of Oulu, Control Engineering Laboratory.

Bauer G., Speck T., Blomer J., Bertling J. \& Speck O. 2010: Insulation capability of the bark of trees with different fire adaptation. Journal of Materials Science 45(21): 5950-5959. DOI: 10.1007/s10853-010-4680$\underline{4}$ 
Bellis D.J., McLeod C.W. \& Satake K. 2002a: $\mathrm{Pb}$ and ${ }^{206} \mathrm{~Pb} /{ }^{207} \mathrm{~Pb}$ isotopic analysis of a tree bark pocket near Sheffield, UK recording historical change in airborne pollution during the 20th Century. The Science of the Total Environment 289: 169-176. DOI: 10.1016/S0048-9697(01)01037-3

Bellis D.J., Satake K., Noda M., Nishimura N. \& McLeod C.W. 2002b: Evaluation of the historical records of lead pollution in the annual growth rings and bark pockets of a 250-year-old Quercus crispula in Nikko, Japan. The Science of the Total Environment 295: 91-100. DOI: 10.1016/S0048-9697(02)00054-2

Berahou A., Auhmani A., Fdil N., Benharref A., Jana M. \& Gadhi C.A. 2007: Antibacterial activity of Quercus ilex bark's extracts. Journal of Ethnopharmacology 112: 426-429. DOI: 10.1016/i.jep.2007.03.032

Berlizov A.N., Blum O.B., Filby R.H., Malyuk I.A. \& Tryshyn V.V. 2007: Testing applicability of black poplar (Populus nigra L.) bark to heavy metal air pollution monitoring in urban and industrial regions. Science of the Total Environment 372: 693-706. DOI: $10.1016 /$ i.scitotenv.2006.10.029

Bittner A. \& Schneider A. 1975: Wertvoller Humus aus Rinde. Holz-Zentralblatt 73-74: 956.

Blanchet P., Cloutier A. \& Riedl B. 2000: Particleboard made from hammer milled black spruce bark residues. Wood Science and Technology 34(1): 11-19. DOI: 10.1007/s002260050003

Blossfeld O. 1977: Einsatzmöglichkeiten für Rinden sind geklärt. Informationen für den Industriezweig Schnittholz und Holzwaren 4: 319.

Boakye P.A., Brierley S.M., Pasilis S.P. \& Balemba O.B. 2012: Garcinia buchananii bark extract is an effective anti-diarrheal remedy for lactose-induced diarrhea. Journal of Ethnopharmacology 142(2): 539-547. DOI: 10.1016/i.jep.2012.05.034

Böhm P., Wolterbeek H., Verburg T. \& Muśilek L. 1998: The use of tree bark for environmental pollution monitoring in the Czech Republic. Environmental Pollution 102: 243-250. DOI: 10.1016/S0269-7491(98)00082$\underline{7}$

Butterfield M. \& Peszlen I. 1997: A fatest háromdimenziós szerkezete. Faipari Tudományos Alapítvány, Budapest.

Castola V., Bighelli A., Rezzi S., Melloni G., Gladiali S., Desjobert J.-M. et al. 2002: Composition and chemical variability of the triterpene fraction of dichloromethane extracts of cork (Quercus suber L.). Industrial Crops and Products 15: 15-22. DOI: 10.1016/S0926-6690(01)00091-7

Castro O., Silva J.M., Devezas T., Silva A. \& Gil L. 2010: Cork agglomerates as an ideal core material in lightweight structures. Materials and Design 31: 425-432. DOI: 10.1016/j.matdes.2009.05.039

Catry F.X., Rego F., Moreira F., Fernandes P.M. \& Pausas J.G. 2010: Post-fire tree mortality in mixed forests of central Portugal. Forest Ecology and Management 260: 1184-1192. DOI: 10.1016/j.foreco.2010.07.010

Chang Y.P. \& Mitchell R.L. 1955: Chemical composition of common North American pulpwood barks. Tappi 38(5): 315-320.

Chen T.Y., Paulitsch M. \& Soto G. 1972: On the suitability of the biological surface mass from spruce thinnings as raw material for particleboard. Holz als Roh- und Werkstoffe 30(1): 15-18.

Cheng X., Deng J., Zhang S.Y., Riedl B. \& Cloutier A. 2006: Impact of bark content on the properties of medium density fiberboard (MDF) in four species grown in eastern Canada. Forest Products 56(3): 64-69.

Chow P., Nakayama F.S., Blahnik B., Youngquist J.A. \& Coffelt T.A. 2008: Chemical constituents and physical properties of guayule wood and bark. Industrial Crops and Products 28: 303-308. DOI: 10.1016/.j.indcrop.2008.03.006

Chow S. \& Obermajer A. 2004: Wood-to-bark adhesion of subalpine fir (Abies lasiocarpa) in extreme temperatures. Wood Science and Technology 38: 391-403. DOI 10.1007/s00226-004-0247-3

Clark A., Phillips D.R. \& Frederick D.J. 1985: Weight, Volume, and Physical Properties of Major Hardwood Species in the Gulf and Atlantic Coastal Plains. USDA, Forest Service, Southeastern Forest Experiment Station Research Paper SE-250. DOI: 10.2737/se-rp-250

Comandini P., Lerma-García M.J., Simó-Alfonso E.F. \& Toschi T.G. 2014: Tannin analysis of chestnut bark samples (Castanea sativa Mill.) by HPLC-DAD-MS. Food Chemistry 157: 290-295. DOI: 10.1016/j.foodchem.2014.02.003 
Conkova M. \& Kubiznakova J. 2008: Lead isotope ratios in tree bark pockets: An indicator of past air pollution in the Czech Republic. Science of the Total Environment 404: 440-445. DOI: 10.1016/j.scitotenv.2008.04.025

Coquet C., Ferré E., Peyronel D., Farra C.D. \& Farnet A.M. 2008: Identification of new molecules extracted from Quercus suber L. cork. Comptes Rendus Biologies 331: 853-858. DOI: 10.1016/j.crvi.2008.08.011

Cordeiro N., Belgacem M.N., Gandini A. \& Neto C.P. 1997: Urethanes and polyurethanes from suberin: 1. Kinetic study. Industrial Crops and Products 6: 163-167. DOI: 10.1016/S0926-6690(96)00212-9

Cordeiro N., Belgacem M.N., Silvestre A.J.D., Neto C.P. \& Gandini A. 1998: Cork suberin as a new source of chemicals. 1. Isolation and chemical characterization of its composition. International Journal of Biological Macromolecules 22: 71-80. DOI: 10.1016/S0141-8130(97)00090-1

Corder S.E. 1976: Properties and uses of bark as an energy source. Research paper 31. Oregon State University, School of Forestry, Forest Research Laboratory, Corvallis, Oregon, 97331.

Cutillas-Barreiro L., Ansias-Manso L., Fernández-Calvino D., Arias-Estévez M., Nóvoa-Munoz J.C., Fernández-Sanjurjo M.J., et al. 2014: Pine bark as bio-adsorbent for $\mathrm{Cd}, \mathrm{Cu}, \mathrm{Ni}, \mathrm{Pb}$ and $\mathrm{Zn}$ : Batch-type and stirred flow chamber experiments. Journal of Environmental Management 144: 258-264. DOI: 10.1016/j.jenvman.2014.06.008

Dedriea M., Jacquet N., Bombeck P-L., Hébert J. \& Richel A. 2015: Oak barks as raw materials for the extraction of polyphenols for the chemical and pharmaceutical sectors: A regional case study. Industrial Crops and Products 70: 316-321. DOI: 10.1016/j.indcrop.2015.03.071

Deppe H.J. \& Ernst K. 1977: Taschenbuch der Spanplattentechnik. DRW-Verlag, Stuttgart.

Dibdiakova J., Gjølsjø S. \& Wang L. 2014: Solid biofuels from forest - fuel specification and quality assurance. Inherent properties of Norway spruce biomass in some geographical locations in South Norway. Report from Norwegian forest and landscape institute 08/2014.

Dickinson M.B. \& Johnson E.A. 2001: Fire effects on trees. In: Johnson E. (ed): Forest Fires: Behavior and Ecological Effects. Chapter 14. Academic Press, 477-525. DOI: 10.1016/b978-012386660-8/50016-7

Dickinson M.B. 2002: Heat transfer and vascular cambium necrosis in the boles of trees during surface fires. In: Viegas D.X. (ed): Forest Fire Research \& Wildland Fire Safety. Millpress, Rotterdam, 190-191.

Diouf P.N., Stevanovic T. \& Cloutier A. 2009: Study on chemical composition, antioxidant and anti-inflammatory activities of hot water extract from Picea mariana bark and its proanthocyanidin-rich fractions. Food Chemistry 113: 897-902. DOI: 10.1016/j.foodchem.2008.08.016

do Vale A.T. \& Elias P.S. 2014: Bark thermal protection level of four tree species and the relationship between bark architecture and heat transfer. Ciência Florestal 24(4): 979-987.

Dost W.A. 1971: Redwood bark fiber in particleboard. Forest Products Journal 21(10): 38-43.

Dubkin M.Sz. \& Daramanján P.M. 1978: Dreveszina i othody jejő pererabotki kak kormovie produkty. Himija dreneszny 1: 3.

Einspahr D.W., Van Eperen R.H. \& Fiscus M.L. 1984: Morphological and bark strength characteristics important to wood/bark adhesion in hardwoods. Wood and Fiber Science 16(3): 339-348.

El-Hasan T., Al-Omari H., Jiries A. \& Al-Nasir F. 2002: Cypress tree (Cupressus sempervirens L.) bark as an indicator for heavy metal pollution in the atmosphere of Amman City, Jordan. Environment International 28: 513-519. DOI: $10.1016 /$ s0160-4120(02)00079-x

FAO 2015: Forest products 2009-2013. FAO Forestry Series No. 48. FAO Statistics Series No. 204.

Fatoki O.S. \& Ayodele E.T. 1991: Zinc and copper levels in tree barks as indicators of environmental pollution. Environmental International 17: 455-460. DOI: 10.1016/0160-4120(91)90279-Y

Fekete Z. 1951: Erdőbecsléstan. Akadémiai Kiadó, Budapest, 145.

Feng S., Cheng S., Yuan Z., Leitch M. \& Xu C. 2013: Valorization of bark for chemicals and materials: A review. Renewable and Sustainable Energy Reviews 26: 560-578. DOI: 10.1016/i.rser.2013.06.024

Fernandes A., Sousa A., Mateus N., Cabral M. \& de Freitas V. 2011: Analysis of phenolic compounds in cork from Quercus suber L. by HPLC-DAD/ESI-MS. Food Chemistry 125: 1398-1405. DOI: 10.1016/j.foodchem.2010.10.016 
Filbakk T., Jirjis R., Nurmi J. \& Høibø O. 2011: The effect of bark content on quality parameters of Scots pine (Pinus sylvestris L.) pellets. Biomass and Bioenergy 35: 3342-3349. DOI: 10.1016/j.biombioe.2010.09.011

Fodor F. 2004: Fásult személyi - Az árulkodó fakéreg. Természetbúvár 59(3): 2-5.

Fradinho D.M., Neto C.P., Evtuguin D., Jorge F.C., Irle M.A., Gil M.H. et al. 2002: Chemical characterisation of bark and of alkaline bark extracts from maritime pine grown in Portugal. Industrial Crops and Products 16: 23-32. DOI: $10.1016 /$ S0926-6690(02)00004-3

Gandini A., Neto C.P. \& Silvestre A.J.D. 2006: Suberin: A promising renewable resource for novel macromolecular materials. Progress in Polymer Sciences 31: 878-892. DOI: 10.1016/i.progpolymsci.2006.07.004

García D.E., Glasser W.G., Pizzi A., Paczkowski S. \& Laborie M.-P. 2015: Hydroxypropyl tannin from Pinus pinaster bark as polyol source in urethane chemistry. European Polymer Journal 67: 152-165. DOI: 10.1016/i.eurpolymi.2015.03.039

Gemici M., Gemici Y. \& Tan K. 2006: Sulphur content of Red pine (Pinus brutia) needles and bark as indicator of atmospheric pollution in Southwest Turkey. Phytologia Balcanica 12(2): 267-272.

Gerencsér K. 2010: Fürészipari technológia (jegyzet). NymE, Fa- és Papíripari Technológiák Intézet, Sopron.

Gertjejansen R. \& Haygreen J.G. 1973: Effect of aspen bark from butt and upper logs on the physical properties of wafer-type and flake-type particleboards. Forest Products Journal 23(9): 66-71.

Ghosh D. 2006: Bark is the Hallmark. Resonance 11(3): 41-50. DOI: $10.1007 / \mathrm{bf02835967}$

Gil L. 1997: Cork powder waste: an overview. Biomass and Bioenergy 13(1-2): 59-61. DOI: 10.1016/S09619534(97)00033-0

Graça J. \& Santos S. 2006: Glycerol-derived ester oligomers from cork suberin. Chemistry and Physics of Lipids 144: 96-107. DOI: $10.1016 / j . c h e m p h y s l i p .2006 .08 .001$

Grace O.M., Prendergast H.D.V., Jager A.K. \& van Staden J. 2003: Bark medicines used in traditional healthcare in KwaZulu-Natal, South Africa: An inventory. South African Journal of Botany 69(3): 301-363. DOI: 10.1016/S0254-6299(15)30318-5

Grodzińska K. 1971: Acidification of tree bark as a measure of air pollution in southern Poland. Bulletin L'Académie Polonaise des Science, Série des Sciences Biologiques 19(3): 189-195.

Grodzińska K. 1978: Acidity of tree bark as a bioindicator of forest pollution in southern Poland. Water, Air and Soil Pollution 7: 3-7.

Grodzińska K. 1979: Tree-bark - sensitive biotest for environment acidification. Environment International 2(3): 173-176. DOI: $10.1016 / 0160-4120(79) 90075-8$

Grodzińska K. 1982: Monitoring of air pollutants by mosses and tree bark. In: Steubing L. \& Jäger H.-J. (eds): Monitoring of Air Pollutants by Plants - Methods and Problems. Dr W. Junk Publishers, The Hague, 3342.

Guidi W., Piccioni E., Ginanni M. \& Bonari E. 2008: Bark content estimation in poplar (Populus deltoides L.) short-rotation coppice in Central Italy. Biomass and Bioenergy 32: 518-524. DOI: 10.1016/j.biombioe.2007.11.012

Gupta G.K. 2009: Development of bark-based environmental-friendly composite panels. Master thesis, Faculty of Forestry, University of Toronto.

Han L.E., Li B.T. \& Lan S.F. 2008: Responses Of The Urban Roadside Trees To Traffic Environment. In: Sorial G.A. \& Hong J (eds): Environmental Science \& Technology (II). American Science Press, Houston, USA, 63-70.

Hargitai L. 2003: Fürészáru. Szaktudás Kiadó Ház Rt., Budapest.

Harkin J.M. \& Rowe J.W. 1971: Bark and its possible uses. USDA. Forest Service, Research note, FPL-091, Forest Products Laboratory.

Härtel O. 1982: Pollutants accumulation by bark. In: Steubing L. \& Jäger H.-J. (eds): Monitoring of Air Pollutants by Plants - Methods and Problems. Dr W. Junk Publishers, The Hague, 137-147.

Heebink B.G. 1974: Particleboards from lodgepole pine forest residue. (USDA Forest Service research paper FPL , 221) U.S. Department of Agriculture, Forest Service, Forest Products Laboratory, Madison, Wiscon$\sin$. 
Heinämäki J., Halenius A., Paavo M., Alakurtti S., Pitkänen P., Pirttimaa M., et al. 2015: Suberin fatty acids isolated from outer birch bark improve moisture barrier properties of cellulose ether films intended for tablet coatings. International Journal of Pharmaceutics 489(1-2): 91-99. DOI: 10.1016/j.ijpharm.2015.04.066

Hengst G.E. \& Dawson J.O. 1993: Bark thermal properties of selected central hardwood species. In: Gillespie A.R., Parker G.R., Pope P.E. \& Rink G. (eds): Proceedings, 9th Central hardwood forest conference, 1993 March 8-10, West Lafayette, IN. General Technical Report NC-161. St. Paul, MN: U.S. Dept. of Agriculture, Forest Service, North Central Forest Experiment Station. 55-75.

Hernández-Olivares F., Bollati M.R., del Rio M. \& Parga-Landa B. 1999: Development of cork-gypsum composites for building applications. Construction and Building Materials 13: 179-186. DOI: 10.1016/S0950$\underline{0618(99) 00021-5}$

Hoong Y.B., Paridah M.T. Luqman C.A., Koh M.P. \& Loh Y.F. 2009: Fortification of sulfited tannin from the bark of Acacia mangium with phenol-formaldehyde for use as plywood adhesive. Industrial Crops and Products 30: 416-421. DOI: 10.1016/i.indcrop.2009.07.012

Hoong Y.B., Paridah M.T., Loh Y.F., Jalaluddin H. \& Chuah L.A. 2011: A new source of natural adhesive: Acacia mangium bark extracts co-polymerized with phenol-formaldehyde (PF) for bonding Mempisang (Annonaceae spp.) veneers. International Journal of Adhesion and Adhesives 31(3): 164-167. DOI: 10.1016/j.jjadhadh.2010.12.002

Jové P., Olivella M.Á. \& Cano L. 2011: Study of the variability in chemical composition of bark layers of Quercus suber $\mathrm{L}$. from different production areas. BioResources 6(2): 1806-1815.

Jyske T., Laakso T., Latva-Mäenpää H., Tapanila T. \& Saranpää P. 2014: Yield of stilbene glucosides from the bark of young and old Norway spruce stems. Biomass and Bioenergy 71: 216-227. DOI: 10.1016/j.biombioe.2014.10.005

Kafle G.K., Chen L., Neibling H. \& He B.B. 2015: Field evaluation of wood bark-based down-flow biofilters for mitigation of odor, ammonia, and hydrogen sulfide emissions from confined swine nursery barns. Journal of Environmental Management 147: 164-174. DOI: 10.1016/j.jenvman.2014.09.004

Kain G., Barbu M-C., Hinterreiter S., Richter K. \& Petuschnigg A. 2013a: Using bark as a heat insulation material. BioResources 8(3): 3718-3731. DOI: 10.15376/biores.8.3.3718-3731

Kain G., Güttler V., Barbu M.-C., Petutschnigg A., Richter K. \& Tondi G. 2014: Density related properties of bark insulation boards bonded with tannin hexamine resin. European Journal of Wood and Wood Products 72: 417-424. DOI: 10.1007/s00107-014-0798-4

Kain G., Heinzmann B., Barbu M.C. \& Petutschnigg A. 2013b: Softwood bark for modern composites. ProLigno 9(4): 460-468.

Kamikawa D., Kuroda K., Inoue M., Kubo S. \& Yoshida T. 2009: Evaluation of combustion properties of wood pellets using a cone calorimeter. Journal of Wood Sciences 55: 453-457. DOI: 10.1007/s10086-009-10611

Kehr E. 1979: Untersuchungen zum Einfluss der Rinde bei der Verarbeitung unentrindeten Holzes in der Deckschicht von Spanplatten. Holztechnologie 1: 32.

Kemppainen K., Siika-aho M., Pattathil S., Giovando S. \& Kruus S. 2014: Spruce bark as an industrial source of condensed tannins and non-cellulosic sugars. Industrial Crops and Products 52: 158-168. DOI: 10.1016/j.indcrop.2013.10.009

Kim Y-G., Lee J-H., Kim S-I., Baek K-H. \& Lee J. 2015: Cinnamon bark oil and its components inhibit biofilm formation and toxin production. International Journal of Food Microbiology 195: 30-39. DOI: 10.1016/j.ijfoodmicro.2014.11.028

Kiran A.W. \& Chandrakant S.M. 2009: Pharmacognostic profiles of bark of Careya arborea Roxb. Journal of Pharmacognosy and Phytotherapy 1(5): 64-66.

Kotina E.L., Van Wyk B.-E. \& Tilney P.M. 2014: Anatomy of the leaf and bark of Warburgia salutaris (Canellaceae), an important medicinal plant from South Africa. South African Journal of Botany 94: 177-181. DOI: 10.1016/j.sajb.2014.06.008 
Kuang Y., Zhou G., Wen D. \& Liu S. 2006: Acidity and conductivity of Pinus massoniana bark as indicators to atmospheric acid deposition in Guangdong, China. Journal of Environmental Sciences 18(5): 916-920. DOI: 10.1016/S1001-0742(06)60014-4

Kuik P. \& Wolterbeek H.T. 1994. Factor-analysis of trace-element data from tree-bark samples in the Netherlands. Environmental Monitoring and Assessment 32: 207-226. DOI: 10.1007/bf00546277

Labosky P.K. Jr., Holleman A., Dick J.W. \& So D.T. 1977: Utilization of bark residues as poultry litter. Forest Products Journal 27(1): 28-32.

Lambert M.J. 1981: Inorganic constituents in wood and bark of New South Wales forest tree species. Research Note No. 45. Forestry Commission of New South Wales, Sydney.

Lawes M.J., Richards A., Dathe J. \& Midgley J.J. 2011: Bark thickness determines fire resistance of selected tree species from fire-prone tropical savanna in north Australia. Plant Ecology 212: 2057-2069. DOI: 10.1007/s11258-011-9954-7

Le Normand M., Mélida H., Holmbom B., Michaelsen T.E., Inngjerdingen M., Bulone V., et al. 2014: Hot-water extracts from the inner bark of Norway spruce with immunomodulating activities. Carbohydrate Polymers 101: 699-704. DOI: 10.1016/i.carbpol.2013.09.067

Lehmann W.F. \& Geimer R.L. 1974: Properties of structural particleboards from Douglas-fir forest residues. Forest Products Journal 24(10): 17-25.

Lehtikangas P. 2001: Quality properties of pelletised sawdust, logging residues and bark. Biomass and Bioenergy 20: 351-360. DOI: 10.1016/S0961-9534(00)00092-1

Li D., Wang W., Tian F., Liao W. \& Bae C.J. 2014: The oldest bark cloth beater in southern China (Dingmo, Bubing basin, Guangxi). Quaternary International 354: 184-189. DOI: 10.1016/i.quaint.2014.06.062

Lin H., Zhang Y-W., Bao Y-L., Wu Y., Sun L-G., Yu C-L., et al. 2013: Secondary metabolites from the stem bark of Juglans mandshurica. Biochemical Systematics and Ecology 51: 184-188. DOI: 10.1016/i.bse.2013.08.010

Lippo H., Poikolainen J. \& Kubin E. 1995: The use of moss, lichen and pine bark in the nationwide monitoring of atmospheric heavy metal deposition in Finland. Water, Air, and Soil Pollution 85: 2241-2246. DOI: 10.1007/BF01186167

Liu Z., Zhang X., Cui W., Zhang X., Li N., Chen J., et al. 2007: Evaluation of short-term and subchronic toxicity of magnolia bark extract in rats. Regulatory Toxicology and Pharmacology 49(3): 160-171. DOI: 10.1016/j.yrtph.2007.06.006

Liverside R.M. \& Murray M.H. 1977: Possible Use of Sawdust in Clay Building Bricks Should Help Many Sawmillers. Australian Forest Industries 2: 48.

Lötschert W. 1983: Immissionsanalysen im Raum Frankfurt unter Verwendung pflanzlicher Bioindikatoren. Verh. Ges. Ökol. 11: 277-290.

Mandiwana K.L., Resane T., Panichev N. \& Ngobeni P. 2006: The application of tree bark as bio-indicator for the assessment of $\mathrm{Cr}(\mathrm{VI})$ in air pollution. Journal of Hazardous Materials B 137: 1241-1245. DOI: 10.1016/j.jhazmat.2006.04.015

Marmor L. \& Randlane T. 2007: Effects of road traffic on bark pH and epiphytic lichens in Tallinn. Folia Cryptogamica Estonica 43: 23-37.

Martin R.E. \& Crist J.B. 1970: Elements of bark structure and terminology. Wood and Fiber Science 2(3): 269279.

Miles P.D. \& Smith W.B. 2009: Specific Gravity and Other Properties of Wood and Bark for 156 Tree Species Found in North America. Res. Note NRS-38. Newtown Square, PA: U.S. Department of Agriculture, Forest Service, Northern Research Station. DOI: 10.2737/NRS-RN-38

Millkin D.E. 1955: Determination of bark volumes and fuel properties. Pulp and paper magazine of Canada 56(13): 106-108.

Miranda I., Gominho J., Mirra I. \& Pereira H. 2012: Chemical characterization of barks from Picea abies and Pinus sylvestris after fractioning into different particle sizes. Industrial Crops and Products 36: 395-400. DOI: $10.1016 /$ j.indcrop.2011.10.035 
Miranda I., Gominho J., Mirra I. \& Pereira H. 2013: Fractioning and chemical characterization of barks of Betula pendula and Eucalyptus globulus. Industrial Crops and Products 41: 299-305. DOI: 10.1016/j.indcrop.2012.04.024

Miyazaki J. \& Hirabayashi Y. 2011: Effect of the addition of Acacia mangium bark on thermosetting of phenolformaldehyde resin. Wood Science and Technology 45(3): 449-460. DOI: 10.1007/s00226-010-0342-6

Molnár S. 2004: Faanyagismeret. Mezőgazdasági Szaktudás Kiadó, Budapest.

Muñoz F., Ballerini A. \& Gacitúa W. 2013: Variability of physical, morphological and thermal properties of Eucalyptus nitens bark fiber. Maderas. Ciencia y tecnología 15(1): 17-30. DOI: 10.4067/S0718221X2013005000002

Muszynski Z. \& McNatt J.D. 1984: Investigations on the use of spruce bark in the manufacture of particleboard in Poland. Forest Products Journal 34(1): 28-35.

Nagy Gy., Novák Á. \& Osztroluczky M. 1998: Zöld szerkezetek. Ybl Miklós Műszaki Főiskola, Multimédia Laboratórium, Publisher Kiadó, Budapest.

Narasimhachari N. \& von Rudloff E. 1961: The chemical composition of the wood and bark extractives of Juniperus horisontalis Moench. Canadian Journal of Chemistry 39: 2572-2581. DOI: 10.1139/v61-339

Naunes E., Qbuilhó T. \& Pereira H. 1999: Anatomy and chemical composition of Pinus pinea L. bark. Annals of Forest Science 56(6): 479-484. DOI: 10.1051/forest:19990604

Navid H., Laszczyk-Lauer M.N., Reichling J. \& Schnitzler P. 2014: Pentacyclic triterpenes in birch bark extract inhibit early step of herpes simplex virus type 1 replication. Phytomedicine 21: 1273-1280. DOI: 10.1016/i.phymed.2014.06.007

Németh K. \& Molnár S. 1983: Az akácfa égésmelegének és fütőértékének vizsgálata. Faipar 33(3): 78-79.

Nemli G. \& Colakoglu G. 2005: Effects of Mimosa Bark Usage on Some Properties of Particleboard, Turkish. Journal of Agriculture and Forestry 29(3): 227-230.

O'Hare G.P. 1974: Lichens and Bark Acidification as Indicators of Air Pollution in West Central Scotland. Journal Biogeography 1: 135-146. DOI: $10.2307 / 3037960$

Obernberger I. \& Thek G. 2004: Physical characterisation and chemical composition of densified biomass fuels with regard to their combustion behaviour. Biomass and Bioenergy 27: 653-669. DOI: 10.1016/i.biombioe.2003.07.006

Olander B. \& Steenari B-M. 1995: Characterization of ashes from wood and straw. Biomass and Bioenergy 8(2): 105-115. DOI: $10.1016 / 0961-9534(95) 00004-Q$

Oramahi H.A. \& Diba F. 2013: Maximizing the Production of Liquid Smoke from Bark of Durio by Studying Its Potential Compounds. Procedia Environmental Sciences 17: 60-69. DOI: 10.1016/i.proenv.2013.02.012

Orlandi L., Vilela F.C., Santa-Cecilia F.V., Dias D.F., Alves-da-Silva G. \& Giusti-Paiva A. 2011: Anti-inflammatory and antinociceptive effects of the stem bark of Byrsonima intermedia A. Juss, Journal of Ethnopharmacology 137(3): 1469-1476. DOI: 10.1016/j.jep.2011.08.032

Oskolski A.A. \& Wyk B.E.V. 2010: Wood and bark anatomy of Centella: scalariform perforation plates support an affinity with the subfamily Mackinlayoideae (Apiaceae). Plant Systematics and Evolution 289(3-4): 127135. DOI: $10.1007 / s 00606-010-0338-6$

Östlund L., Ahlberg L., Zackrisson O., Bergman I. \& Arno S. 2009: Bark-peeling, food stress and tree spirits the use pf pine inner bark for food in Scandinavia and North America. Journal of Ethnobiology 29(1): 94 112. DOI: DOI: $10.2993 / 0278-0771-29.1 .94$

Palma G., Freer J. \& Baeza J. 2003: Removal of metal ions by modified Pinus radiata bark and tannins from water solutions. Water Research 37: 4974-4980. DOI: 10.1016/j.watres.2003.08.008

Patnukao P. \& Pavasant P. 2008: Activated carbon from Eucalyptus camaldulensis Dehn bark using phosphoric acid activation. Bioresource Technology 99(17): 8540-8543. DOI: 10.1016/j.biortech.2006.10.049

Pecznik P. \& Körmendi P. (eds) 1997: Hőenergia gazdálkodás- biomassza tüzelés. Földművelésügyi Minisztérium, Müszaki Intézet, Gödöllö.

Pedieu R., Riedl B. \& Pichette A. 2008a: Properties of white birch (Betula papyrifera) outer bark particleboards with reinforcement of coarse wood particles in the core layer. Annals of Forest Science 65(7): 1-9. DOI: 10.1051/forest:2008053 
Pedieu R., Riedl B. \& Pichette A. 2008b: Physical and mechanical properties of panel based on outer bark of white birch: mixed panels with wood particles versus wood fibers. Maderas. Ciencia y tecnología 10(3): 195-206. DOI: 10.4067/S0718-221X2008000300003

Pedieu R., Riedl B. \& Pichette A. 2009: Properties of mixed particleboards based on white birch (Betula papyrifera) inner bark particles and reinforced with wood fibres. European Journal of Wood and Wood Products 67(1): 95-101. DOI: 10.1007/s00107-008-0297-6

Pinto P.C.R.O., Sousa A.F., Silvestrea A.J.D., Neto C.P., Gandini A., Eckerman C. et al. 2009: Quercus suber and Betula pendula outer barks as renewable sources of oleochemicals: A comparative study. Industrial Crops and Products 29(1): 126-132. DOI: 10.1016/j.indcrop.2008.04.015

Piotrowska P., Skoglund N., Grimm A., Boman C., Öhman M., Zevenhoven M., et al. 2012: Systematic studies of ash composition during the co-combustion of rapeseed cake and bark. Accepted for the proceedings of the 21st International Conference on Fluidized Bed Combustion, Naples (Italy), June 2012.

Poikolainen J. 1997: Sulphur and heavy metal concentrations in Scots pine bark in northern Finland and the Kola Peninsula. Water Air Soil Pollution 93: 395-408. DOI: 10.1023/A:1022160930526

Polubojárinov O.J. 1976: Plotnoszty dreveszini (A faanyag sürüsége). Leszneja pramislenoszty, Moszkva.

Ponomarenko J., Trouillas P., Martin N., Dizhbite T., Krasilnikova J. \& Telysheva G. 2014: Elucidation of antioxidant properties of wood bark derived saturated diarylheptanoids: A comprehensive (DFT-supported) understanding. Phytochemistry 103: 178-187. DOI: $10.1016 /$ i.phytochem.2014.03.010

Popp M.P., Johnson J.D. \& Massey T.L. 1991: Stimulation of resin flow in slash and loblolly pine by bark beetle vectored fungi. Canadian Journal of Forest Research 21(7): 1124-1126. DOI: $10.1139 / \times 91-155$

Portik K.I. 2006: A fenyő hasznositása a Székelyföldön. Székelyföld - kulturális folyóirat 10(12).

Poyraz M.U. \& Mat A. 2014: The miracle bark Chinhona and malaria in the Ottoman Empire. XI. National Conference on the History of Turkish Pharmacy, 25-28 May 2014., Poster Session, Abstract, Lokman Hekim Journal 60.

Ragland K.W. \& Aerts D.J. 1991: Properties of wood for combustion analysis. Bioresource Technology 37: 161-168. DOI: 10.1016/0960-8524(91)90205-X

Randall J.M., Hautala E., Waiss A.C., \& Tschernitz J.L. 1976: Modified barks as scavengers for heavy metal ions. Forest Products Journal 26: 46-50.

Rapaics R. 1940: A fakéreg. A természet 36(1): 2-5.

Rápóti J. \& Romváry V. 1974: Gyógyító növények. Medicina, Budapest.

Ressel J.B. 2006: Wood yard operations. In: Sixta H. (ed): Handbook of Pulp. WILEY-VCH Verlag GmbH \& Co. KGaA, Weinheim. 69-107. DOI: 10.1002/9783527619887.ch3

Robertson L. 2014: Rethinking Material Culture: Ugandan Bark Cloth. Published in Textile Society of America 2014 Biennial Symposium Proceedings: New Directions: Examining the Past, Creating the Future, Los Angeles, California, September 10-14.

Rowe J.W., Bower C.L. \& Wagner E.R. 1969: Extractives of jack pine bark: Occurrence of cis- and transpinosylvin dimethyl ether and ferulic acid esters. Phytochemistry 8: 235-241. DOI: 10.1016/s00319422(00)85819-7

Saarela K.E., Harju L., Rajander J., Lill J.O., Heselius S.J., Lindroos A. \& Mattsson K. 2005: Elemental analyses of pine bark and wood in an environmental study. Science of The Total Environment 343(1-3): 231-241. DOI: 10.1016/..scitotenv.2004.09.043

Saayman H.M. \& Oatley J.A. 1976: Wood adhesives from wattle bark extract. Forest Products Journal 27: 7186.

Salem N.M. \& Awwad A.M. 2014: Biosorption of Ni(II) from electroplating wastewater by modified (Eriobotrya japonica) loquat bark. Journal of Saudi Chemical Society 18: 379-386. DOI: $10.1016 /$ j.jscs.2011.07.008

Santamaría J.M. \& Martin A. 1997: Tree bark as a bioindicator of air pollution in Navarra, Spain. Water, Air, and Soil Pollution 98: 381-387. DOI: 10.1023/A:1026431211784

Santos E.N., Lima J.C.S., Noldin V.F., Cechinel-Filho V., Rao V.S.N., Lima E.F., et al. 2011: Anti-inflammatory, antinociceptive, and antipyretic effects of methanol extract of Cariniana rubra stem bark in animal models. Anais da Academia Brasileira de Ciências 83(2): 557-566. DOI: 10.1590/s0001-37652011005000006 
Santos S.A.O., Pinto P.C.R.O., Silvestre A.J.D. \& Neto C.P. 2010: Chemical composition and antioxidant activity of phenolic extracts of cork from Quercus suber L. Industrial Crops and Products 31: 521-526. DOI: 10.1016/j.indcrop.2010.02.001

Sári J.Sz. 2008: Tőzeghelyettesítő anyagok a paprikahajtatásban. Doktori Értekezés. Budapesti Corvinus Egyetem, Talajtan és Vízgazdálkodási Tanszék, Budapest.

Sarkar R., Chaudhary S.K., Sharma A., Yadav K.K., Nema N.K., Sekhoacha M., et al. 2014: Anti-biofilm activity of Marula - A study with the standardized bark extract. Journal of Ethnopharmacology 154: 170-175. DOI: 10.1016/.j.jep.2014.03.067

Satake K., Tanaka A. \& Kimura K. 1996: Accumulation of lead in tree trunk bark pockets as pollution time capsules. The Science of the Total Environment 181: 25-30. DOI: 10.1016/0048-9697(95)04955-X

Sato Y., Konishi T., \& Takahashi A. 2004: Development of Insulation Material Using Natural Tree Bark. Transactions of the Materials Research Society of Japan 29(5): 1937-1940.

Sawidis T., Breuste J., Mitrovic M., Pavlovic P. \& Tsigaridas K. 2011: Trees as bioindicator of heavy metal pollution in three European cities. Environmental Pollution 159: 3560-3570. DOI: 10.1016/i.envpol.2011.08.008

Schafer J.L., Breslow B.P., Hohmann M.G. \& Hoffmann W.A. 2015: Relative bark thickness is correlated with tree species distribution along a fire frequency gradient. Fire Ecology 11(1): 74-87. DOI: 10.4996/fireecology.1101074

Schneider A. \& Baums A. 1970: Wohin mit der Rinde? DRW-Verlag GmbH, Stuttgart.

Schulz H., Popp P., Huhn G., Stärk H.-J. \& Schürmann G. 2000a: Biomonitoring of airborne inorganic and organic pollutants by means of pine tree barks. - I. Temporal and spatial variations. In: Smodis B. (ed): Biomonitoring of Atmospheric Pollution (with Emphasis on Trace Elements) BioMAP, IAEA-TECDOC-1152, International Atomic Energy Agency, Vienna, 149-158.

Schulz H., Schulz U., Huhn G. \& Schürmann G. 2000b: Biomonitoring of airborne inorganic and organic pollutants by means of pine tree barks. - II. Deposition types and impact levels. In: Smodis B. (ed): Biomonitoring of Atmospheric Pollution (with Emphasis on Trace Elements) BioMAP, IAEA-TECDOC-1152, International Atomic Energy Agency, Vienna, 159-167.

Schweizer G. \& Meigel P. 1977: Über die Verwertung von Entrindungsabfall als Porosierungsstoff in der Ziegelindustrie. Das Papier 31(10A): V27-V32.

Schweizer G. 1975: Versuche zur Optimierung der Schlammentwässerung und zur Verwertung von Rinde und Schlamm in der Ziegelindustrie. Wochenblatt für Papierfabrikation 103(22): 833-839.

Şen A., Isabel Miranda I., Santos S., Graça J. \& Pereira H. 2010: The chemical composition of cork and phloem in the rhytidome of Quercus cerris bark. Industrial Crops and Products 31: 417-422. DOI: 10.1016/.indcrop.2010.01.002

Şen A., Quilhó T. \& Pereira H. 2011: The cellular structure of cork from Quercus cerris var. cerris bark in a materials' perspective. Industrial Crops and Products 34: 929-936. DOI: 10.1016/j.indcrop.2011.02.015

Şensöz S. 2003: Slow pyrolysis of wood barks from Pinus brutia Ten. and product compositions. Bioresource Technology 89: 307-311. DOI: 10.1016/S0960-8524(03)00059-2

Sopp L. \& Kolozs L. 2000: Fatömegszámítási táblázatok. Állami Erdészeti Szolgálat, Budapest, 24-29.

Starecki A. 1979: Spanplatten aus Holz mit Rindenanteil. Holztechnologie 2: 108.

Staxäng B. 1969: Acidification of bark of some deciduous trees. Oikos 20(2): 224-230. DOI: $10.2307 / 3543190$

Steindor K., Palowski B., Góras P. \& Nadgórska-Socha A. 2011: Assessment of bark reaction of selected tree species as an indicator of acid gaseous pollution. Polish Journal of Environment Studies 20(3): 619-622.

Suzuki K. 2006: Characterisation of airborne particulates and associated trace metals deposited on tree bark by ICP-OES, ICP-MS, SEM-EDX and laser ablation ICP-MS. Atmospheric Environment 40: 2626-2634. DOI: $10.1016 /$ /.atmosenv.2005.12.022

Swieboda M. \& Kalemba A. 1979: The bark of Scots pine (Pinus sylvestris L.) as a biological indicator of atmospheric air pollution. Acta Societatis Botanicorum Poloniae 48(4): 539-549. DOI: 10.5586/asbp. 1979.045

Szalay L. 1981: A fahulladék hasznosítása. Műszaki Könyvkiadó, Budapest. 
Szatyor Gy. 1986: Faművesség. Mezőgazdasági Kiadó, Budapest.

Szendrey I.1986: Faipari kémiai technológia 1. Egyetemi jegyzet, Sopron.

Terangpi R., Basumatary R., Tamuli A.K. \& Teron R. 2013: Pharmacognostic and Physicochemical evaluation of stem bark of Acacia pennata (L.) Willd., a folk plant of the Dimasa tribe of Assam. Journal of Pharmacognosy and Phytochemistry 2(2): 134-140.

Thalhamer B. \& Himmelsbach M. 2014: Characterization of quillaja bark extracts and evaluation of their purity using liquid chromatography-high resolution mass spectrometry. Phytochemistry Letters 8: 97-100. DOI: 10.1016/.jphytol.2014.02.009

Tóth L. 2005: Gyógynövények, drogok, fitoterápia. Kossuth Egyetemi Kiadó, Debrecen.

Ugolev B.N. 1986: Dreveszinovedenie sz osznovami lesznogo tovarovedenija. Lesznaja promüslennoszty, Moszkva.

Usta M. \& Kara Z. 1997: The chemical composition of wood and bark of Cedrus libani A. Rich. Holz als Rohund Werkstoff 55(2-4): 268. DOI: 10.1007/BF02990561

Vajda M. 2002: Kezelt fakéreg lipidek eltávolítására vízböl. Müszaki Információ. Környezetvédelem (ISNN: 0209-5769). 2002(17-18): 61-70.

Valentín L., Kluczek-Turpeinen B., Willför S., Hemming J., Hatakka A., Steffen K. et al. 2010: Scots pine (Pinus sylvestris) bark composition and degradation by fungi: Potential substrate for bioremediation. Bioresource Technology 101: 2203-2209. DOI: 10.1016/j.biortech.2009.11.052

Vasconcelos C.F., Maranhão H.M., Batista T.M., Carneiro E.M., Ferreira F., Costa J., et al. 2011: Hypoglycaemic activity and molecular mechanisms of Caesalpinia ferrea Martius bark extract on streptozotocin-induced diabetes in Wistar rats. Journal of Ethnopharmacology 137(3): 1533-1541. DOI: 10.1016/j.jep.2011.08.059

Vázquez G., Fontenla E., Santos J., Freire M.S., González-Álvarez J. \& Antorrena G. 2008: Antioxidant activity and phenolic content of chestnut (Castanea sativa) shell and eucalyptus (Eucalyptus globulus) bark extracts. Industrial crops and products 28: 279-285. DOI: 10.1016/j.indcrop.2008.03.003

Venkatesan T., Choi Y-W. \& Kim Y-K. 2015: The cytotoxic nature of Acanthopanax sessiliflorus stem bark extracts in human breast cancer cells. Saudi Journal of Biological Sciences 22(6): 752-759. DOI: 10.1016/j.sjbs.2015.04.004

Venter P.B., Senekal N.D., Kemp G., Amra-Jordaan M., Khan P., Bonnet S.L. et al. 2012: Analysis of commercial proanthocyanidins. Part 3: The chemical composition of wattle (Acacia mearnsii) bark extract. Phytochemistry 83: 153-167. DOI: $10.1016 /$ i.phytochem.2012.07.012

Verkerk P.J., Anttila P., Eggers J., Lindner M. \& Asikainen A. 2011: The realisable potential supply of woody biomass from forests in the European Union. Forest Ecology and Management 261(11): 2007-2015. DOI: 10.1016/i.foreco.2011.02.027

Wang G.G. \& Wangen S.R. 2011: Does frequent burning affect longleaf pine (Pinus palustris) bark thickness? Canadian Journal of Forest Research 41(7): 1562-1565. DOI: 10.1139/x11-074

Wang L. \& Dibdiakova J. 2014: Characterization of Ashes from Different Wood Parts of Norway Spruce Tree. Chemical Engineering Transactions 37: 37-42. DOI: 10.3303/CET1437007

Wang Q., Zhu C., Wang Y., Huang Z., Li Z. \& Huang B. 2003: A novel sampling method for present and historical monitoring of air pollution by using tree bark. Environmental Chemistry 22(3): 250-254.

Weißmann G. 1976: Reinigung Ölhaltiger Abwässer mit Rinde. Holz Zentralblatt 50: 661-662.

Whiting D., Tolan R., Mecham B. \& Bauer M. 2011: Mulching with Wood/Bark Chips, Grass Clippings, and Rock. Colorado Master Gardenersm Program, Colorado Gardener Certificate Training, Colorado State University Extension, \#245.

Winkler A. 1978: A fakéreg struktúrájának és megfelelő fizikai- mechanikai tulajdonságú fakéreglapok gyárthatóságának kapcsolata. Kandidátusi értekezés, Soproni Egyetem, Faipari Mérnöki Kar, Sopron.

Yemele M.C.N., Koubaa A., Cloutier A., Soulounganga P. \& Wolcott M. 2010: Effect of bark fiber content and size on the mechanical properties of bark/HDPE composites. Composites Part A: Applied Science and Manufacturing 41(1): 131-137. DOI: 10.1016/j.compositesa.2009.06.005 
Young H.E. 1971: Preliminary estimates of bark percentages and chemical elements in complete trees of eight species in Maine. Forest Products Journal 21(5): 56-59. [Aspen Bibliography. Paper 5461.]

Zhang L., Chen J., Wang Y., Wu D. \& Xu M. 2010: Phenolic Extracts from Acacia mangium Bark and Their Antioxidant Activities. Molecules 15: 3567-3577. DOI: 10.3390/molecules15053567

Barboutis I. \& Lykidis C. 2014: The Effects of Bark on Fuel Characteristics of some Evergreen Mediterranean Hardwood Species. Proceedings of the 57th International Convention of Society of Wood Science and Technology, June 23-27, 2014, Zvolen, Slovakia, 533-540.

\section{ONLINE FORRÁSOK}

Melin S. 2008: Bark as feedstock for production of wood pellets. Wood Pellet Association of Canada. http://www.pellet.org/images/2008-12-11_Bark_as_feedstock_for_Production_of_Wood_Pellets_Report_December_2008.pdf Letöltés ideje: 2016. 11. 14.

Vajda B. 2006: Parafa az építőiparban. http://fenntarthato.hu/ Letöltés ideje: 2016. 02.15.

Érkezett: 2019. július 15.

Közlésre elfogadva: 2019. november 15. 